\title{
1. INTRODUCTION AND EXPLANATORY NOTES, LEG 39, DEEP SEA DRILLING PROJECT
}

\author{
Peter R. Supko,' Scripps Institution of Oceanography, La Jolla, California \\ Katharina Perch-Nielsen, Eidg. Technische Hochschule Zürich, Switzerland \\ and \\ Richard L. Carlson, University of Washington, Seattle, Washington
}

\section{BACKGROUND AND PLANNING OF LEG 39}

Unlike most recent Deep Sea Drilling Project cruises, Leg 39 was not scientifically planned as a "theme" cruise, on which a number of sites are drilled to address a single scientific problem area. Rather, the general geographic area for drilling was dictated largely by logistics, since it was necessary to get Glomar Challenger from her recently completed Norwegian Sea drilling during the Northern Hemisphere summer to Cape Town in time to begin a third season of Antarctic and Southern Ocean drilling during the Southern Hemisphere summer. In order to optimize the ratio of drilling time to steaming time on the long cruise from Amsterdam to Cape Town, a cruise track to the western part of the South Atlantic, taking advantage of winds and currents, was indicated. The result was the longest cruise to date in the DSDP program, both in terms of miles (9985) and days (72, with a one-day port call in Recife, Brazil, to change the entire Global Marine crew and a part of the scientific staff). Although the Antarctic drilling program was cancelled shortly before Glomar Challenger arrived in Cape Town, it was well that logistics partially controlled the routing of the ship to the southwest Atlantic, since there were a number of important sites to be drilled and there is little likelihood that a deep ocean drill ship will be operating in the southwest Atlantic in the foreseeable future. Glomar Challenger track and drill sites are shown in Figure 1.

General areas to be drilled during Leg 39 were chosen before the cruise by the JOIDES Atlantic Advisory Panel. Because of a failure to obtain diplomatic clearance to drill the North Brazilian Ridge, which is in the territorial waters claimed by Brazil, the alternate Site 354 on the Ceará Rise was chosen by the co-chief scientists, with the concurrence of the Chairman of the JOIDES Planning Committee. Site 359 in the seamount province of the Walvis Ridge is a contingency site chosen at sea to utilize operational time remaining after we were blown off our last planned site.

Leg 39 scientific goals were to:

1) drill a presumed section of oceanic layer 3 in the offset region of the Vema Fracture Zone (Site 353);

2) collect a biostratigraphic section on the Ceará Rise (Site 354), determine the nature and age of a

\footnotetext{
'Present address: National Research Institute for Oceanology, P.O. Box 320, Stellenbosch, South Africa.
}

prominent reflector there, and determine the nature and age of basement;

3) date basement between magnetic anomalies 32 and 33 in the Argentine Basin (Site 358), and 33 and 34 in the Brazil Basin (Site 355);

4) obtain as complete sedimentary sections as time would permit at the Ceará Rise, Brazil Basin, the Argentine Basin, São Paulo Plateau (Site 356), and Rio Grande Rise (Site 357) to support the major objective of the cruise, improving our knowledge of paleocirculation changes and the overall geologic history of the South Atlantic Ocean;

5) determine the nature and age of prominent reflecting Horizons A and B in the Argentine Basin.

\section{SUMMARY OF SCIENTIFIC RESULTS}

Detailed scientific results at each site are reported in the Site Report chapters (Chapters 2 through 8, this volume), and an overall synopsis has been published earlier in a general format (Perch-Nielsen, Supko, et al., 1975); most of these general observations remain essentially unchanged and will not be repreated here in that format. At the end of this volume (Supko and Perch-Nielsen), a general cruise synthesis is presented in terms of major problems and processes in marine geology, such as the occurrence of hiatuses in cored sequences and paleocurrent implications, nature of sedimentatary facies accumulation at continental margin and basin sites, dating of marine magnetic anomalies, nature of seismic reflecting horizons, and origin of and sedimentation history at oceanic rises.

The following section offers a brief synopsis of major findings at each drilled site. Figure 2 shows the major sediment facies deposited at each Leg 39 site as a function of geologic time. Actual hiatuses are shown as breaks of appropriate duration in the sediment column, and inferred hiatuses or periods of slow sediment accumulation are shown as partial indentations. Sediment accumulation rates (uncorrected for compaction) are shown in Figure 3 and site data and coring statistics are listed in Table 1.

\section{Vema Fracture Zone (Site 353)}

Despite several attempts, we did not succeed in sampling lower oceanic crust at the Vema Fracture Zone. Our first attempt was interrupted by a mechanical failure before basement was reached, and two successive attempts terminated in basalt-cobble zones that impeded drilling. The recovered basalt 


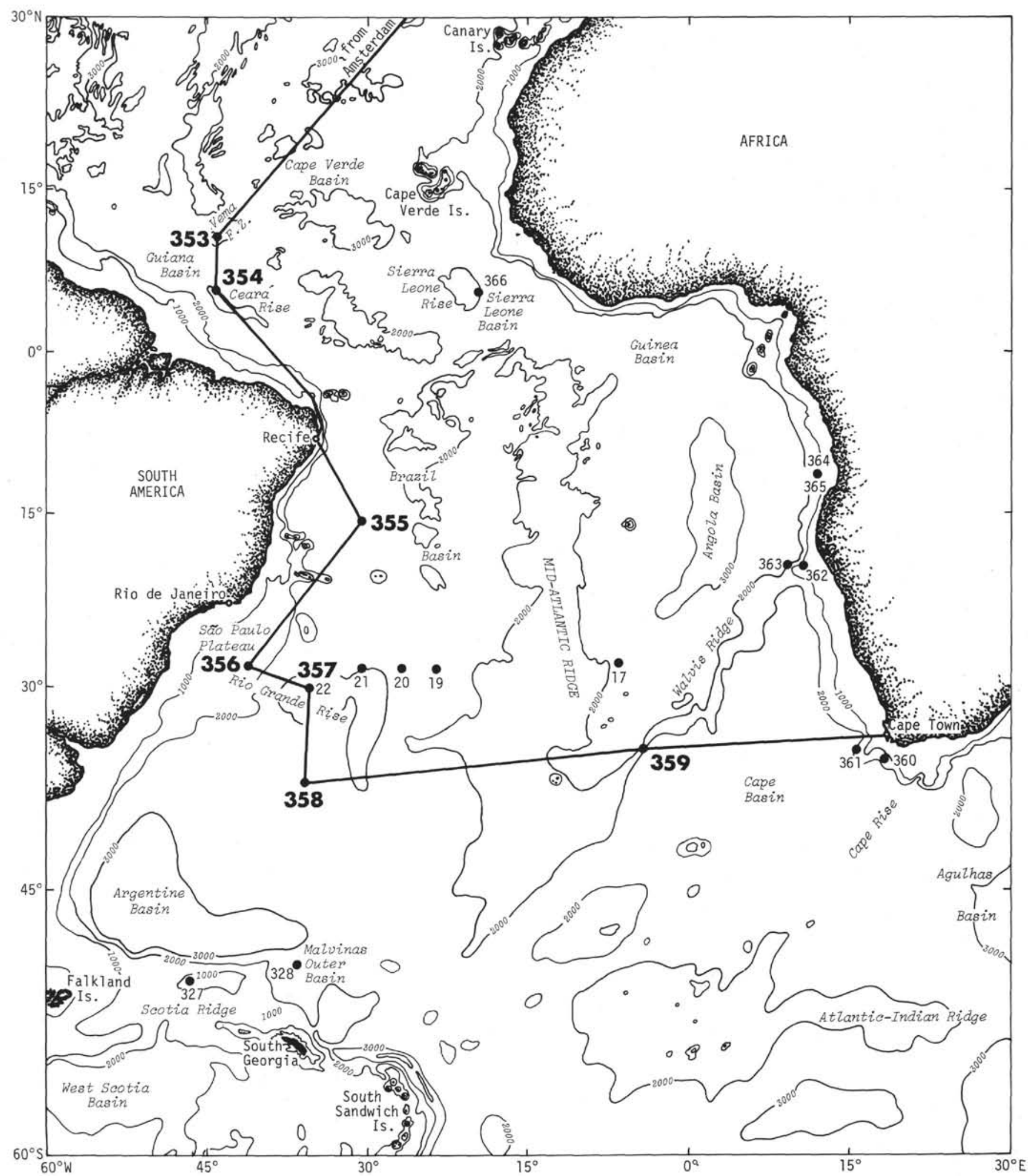

Figure 1. Glomar Challenger Leg 39 track and drill sites; selected Leg 3, 36, 40, and 41 sites also shown.

cobbles $(1.1 \mathrm{~m})$ probably represent talus derived from the upper crustal part of the fracture zone.

We penetrated 384 meters of Pleistocene turbidite sediments. The bulk of the material was derived from the Amazon Cone, as had earlier been reported (Bader, Gerard, et al., 1970); our results show that the wall of the fracture zone itself also serves as a source of sediment. 


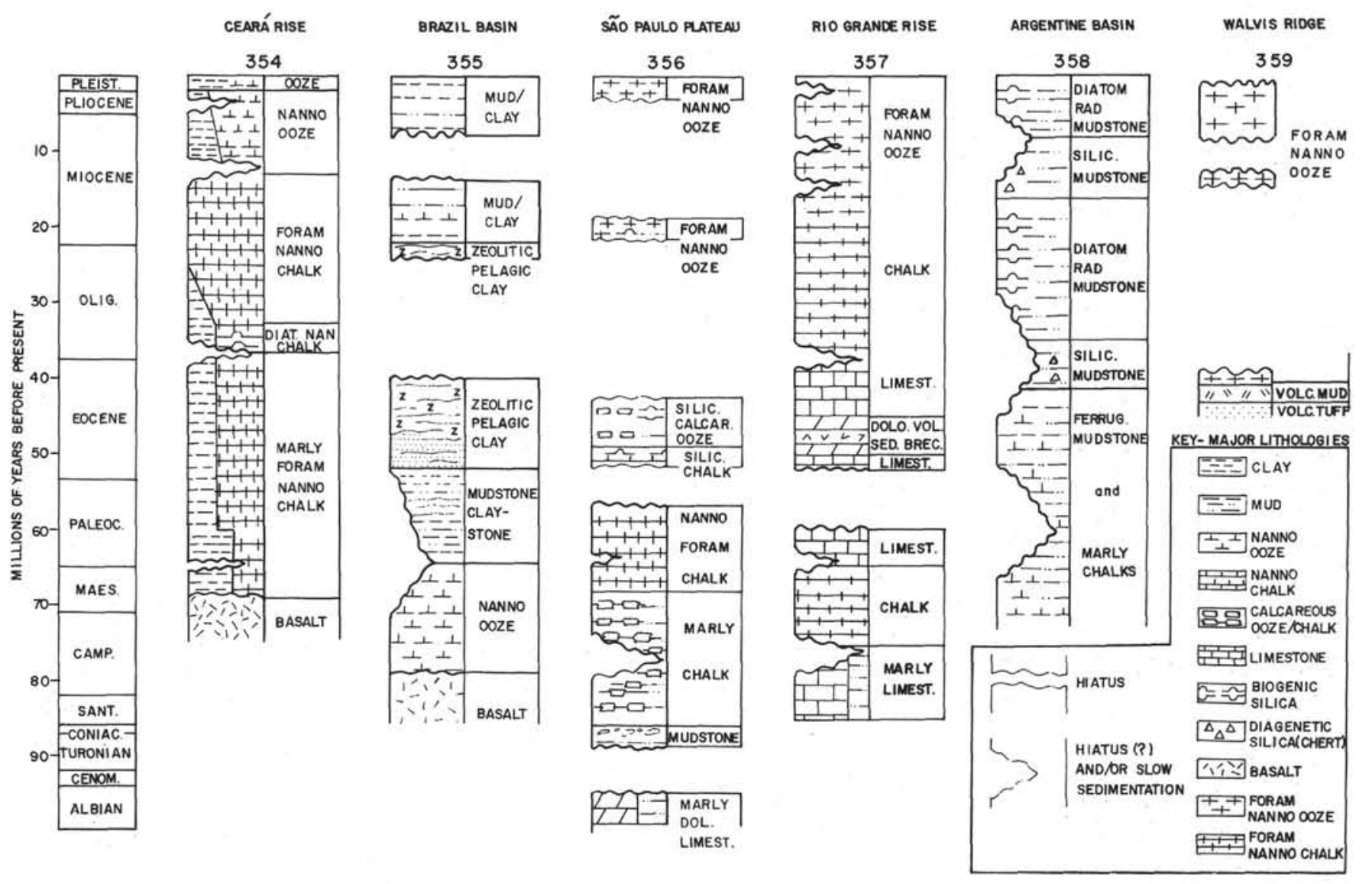

Figure 2. Sediment facies as a function of age at Leg 39 sites.

\section{Ceará Rise (Site 354)}

At this site we penetrated 886 meters of sediment above acoustic basement, which is diabasic basalt; we are unsure as to whether it is a sill or flow. The lowermost sediments are reddish ferruginous marly chalks, of early Maestrichtian age, which may have formed when accumulating sediment was being affected by processes associated with generation of ocean crust. The entire sediment column consists of open marine biogenic carbonate ooze deposited under welloxygenated conditions. Siliceous sediments (diatomaceous nannofossil ooze) are important only in the Oligocene, and an abundant terrigenous component occurs only in upper Miocene and younger sediments, the result of the beginning of drainage from the Amazon River into the Atlantic Ocean. The terrigenous sediment has apparently been added both as particles settling through the water column and as distal facies of turbidity currents.

The Ceará Rise section at Site 354 is very similar in age, composition, and paleo-environmental indicators to the section drilled at Site 366 on the Sierra Leone Rise (Lancelot, Seibold, et al., 1975). We suggest that the two features had a common origin at a locus of basaltic outpouring at the spreading center at about 80 m.y.B.P., a time when South Atlantic spreading direction may have changed (Le Pichon and Hayes, 1971; Le Pichon and Fox, 1971; Pitman and Talwani,
1972). The igneous mound formed, then broke apart; the Ceará Rise subsided as it moved west and the Sierra Leone Rise subsided as it moved east. Both sites have very similar sedimentary histories.

\section{Brazil Basin (Site 355)}

A 449-meter sedimentary section was drilled and cored above igneous basement, a typical ocean ridge tholeiite (Fodor et al., this volume) with a $\mathrm{K} / \mathrm{Ar}$ age of $78.1 \pm 9$ m.y. This is in agreement with the early Campanian age of the basal nannofossil oozes; we estimate a basement age of 76.5 to 78 m.y. at Site 355 , which is between anomalies 33 and 34 (Supko and Perch-Nielsen, this volume). The Campanian to lower Maestrichtian nannofossil ooze contains numerous veins of calcite (satin spar) which are presumably diagenetic. The basal ooze is overlain by 16 meters of undated zeolitic and ferruginous clays, which in turn are overlain by lower Eocene zeolitic pelagic clays. Because of the inability to date the intervening sediment, we can only state that the site passed below the CCD sometime between the early Maestrichtian and the early Eocene. Assuming normal crustal subsidence (Sclater et al., 1971), subsidence below the compensation level in the early Maestrichtian would give a CCD level at that time of about 3000 meters; if the site passed below the CCD as late as early Eocene, the CCD depth at that time would have been about 3700 meters. 


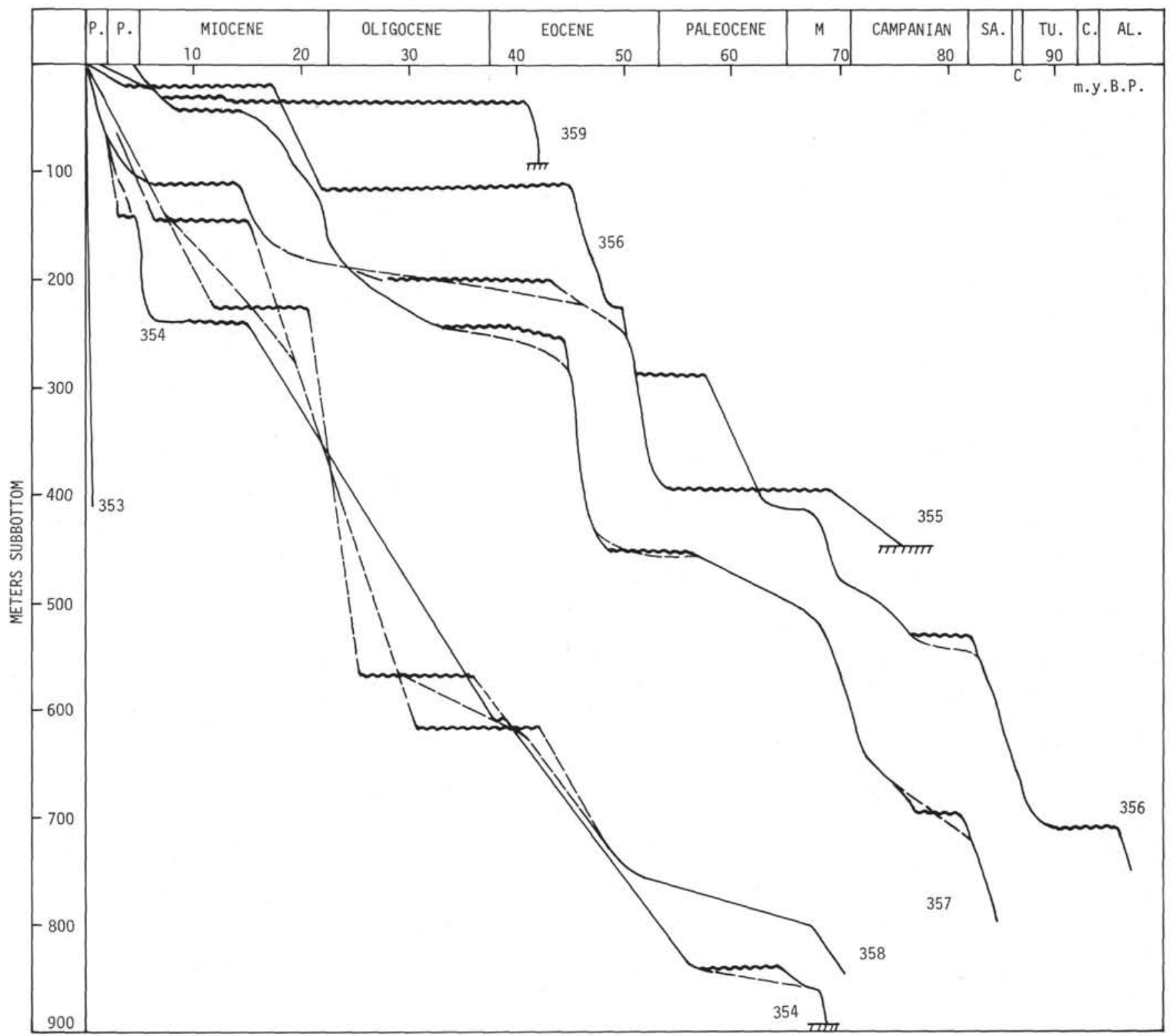

Figure 3. Sediment accumulation at Leg 39 sites.

TABLE 1

Operational Statistics, Leg 39

\begin{tabular}{|c|c|c|c|c|c|c|c|c|c|}
\hline Site & Dates & Latitude & Longitude & $\begin{array}{l}\text { Water } \\
\text { Depth } \\
\text { (m) }\end{array}$ & $\begin{array}{l}\text { Penetration } \\
\text { (m) }\end{array}$ & $\begin{array}{l}\text { No. of } \\
\text { Cores }\end{array}$ & $\begin{array}{l}\text { Meters } \\
\text { Cored }\end{array}$ & $\begin{array}{c}\text { Meters } \\
\text { Recovered }\end{array}$ & $\begin{array}{c}\text { Recovery } \\
\text { (\%) }\end{array}$ \\
\hline 353 & $21-25$ Oct. & $10^{\circ} 55^{\prime} \mathrm{N}$ & $44^{\circ} 02.25^{\prime} \mathrm{W}$ & 5165 & 384.5 & 5 & 23.5 & 9.6 & 23 \\
\hline 354 & 27-31 Oct. & $05^{\circ} 53.95^{\prime} \mathrm{N}$ & $44^{\circ} 11.78^{\prime} \mathrm{W}$ & 4052 & 900.0 & 19 & 211.0 & 119.0 & 56 \\
\hline 355 & 8-12 Nov. & $15^{\circ} 42.59^{\prime} \mathrm{S}$ & $30^{\circ} 36.03^{\prime} \mathrm{W}$ & 4896 & 460.0 & 22 & 207.5 & 118.1 & 57 \\
\hline 356 & 16-21 Nov. & $28^{\circ} 17.22^{\prime} \mathrm{S}$ & $41^{\circ} 05.28^{\prime} \mathrm{W}$ & 3203 & 741.0 & 4 & 437.0 & 333.5 & 77 \\
\hline 357 & 23-28 Nov. & $30^{\circ} 00.25^{\prime} \mathrm{S}$ & $35^{\circ} 33.59^{\prime} \mathrm{W}$ & 2109 & 796.5 & 51 & 473.0 & 345.2 & 73 \\
\hline 358 & 30 Nov./3 Dec. & $37^{\circ} 39.31^{\prime} \mathrm{S}$ & $35^{\circ} 57.82^{\prime} \mathrm{W}$ & 5000 & 842.0 & 16 & 152.0 & 89.3 & 59 \\
\hline 359 & 10-11 Dec. & $34^{\circ} 59.10^{\prime} \mathrm{S}$ & $04^{\circ} 29.83^{\prime} \mathrm{W}$ & 1658 & $\underline{107.0}$ & 8 & 69.0 & 42.4 & 61.5 \\
\hline Total & & & & & 4231.0 & 167 & 1573.0 & 1175.2 & \\
\hline
\end{tabular}

The Cenozoic section consists of zeolitic pelagic clays and terrigenous muds and clays. Numerous laminae of sand and silt are present, indicating contributions by turbidity currents. The laminae contain abundant zeolites, presumably authigenic. The middle Eocene section contains significant quantities of siliceous 
biogenic remains. Bioclastic carbonate debris was introduced by turbidity currents in the Miocene. A hiatus is present in the middle Miocene, a very probable hiatus exists between the middle Eocene and the upper Oligocene, and there is a hiatus or period of very slow sediment accumulation between the middle Maestrichtian and the uppermost Paleocene.

\section{São Paulo Plateau (Site 356)}

The oldest sediments recovered on Leg 39 were the upper Albian laminated dolomitic limestones at this site, which was abandoned at 741 meters because of lack of time and a very slow coring rate. Earlier geophysical studies and drilling results at Site 364 in the Angola Basin (Bolli, Ryan, et al., 1975) indicate that Aptian salt probably exists on the Angolan margin and on the Brazilian margin on the São Plateau. The late Albian dolomitic limestones thus represent sedimentary conditions some 6-8 m.y. after the presumed deposition of the salt. Benthic foraminifer assemblages indicate a depth of about 1000 meters at the time the dolomitic limestones were deposited. Thin ungraded laminae of pure calcium carbonate indicate winnowing by currents; coarse sand-sized layers with abundant quartz indicate turbidity currents from the Brazilian margin. Thus, both eroding and depositing currents were active in the late Albian; this combination of processes is also apparent upward in the section, and is not surprising since the site is near the bottom of a trough on the north side of the ridge that forms the southern boundary of the plateau.

The limestones are overlain by Turonian-Coniacian black pyritiferous calcareous mudstones and nannofossil marls. The deposit is conglomeratic in part, which indicates some introduction from outside the basin. Other sections of pyritiferous mudstone, however, have gradational contacts indicating in-situ deposition. The reduced sediments are interlayered with burrowed light gray oozes containing benthic foraminifers; this indicates cyclic oxidizing and reducing conditions. We do not know whether the Turonian-Coniacian period of sedimentation under cyclic reducing conditions was a local event or was associated with a more general basin-wide phenomenon in the Atlantic Ocean north of the São Paulo Plateau-Walvis Ridge (see discussion in Supko and Perch-Nielsen, this volume).

Post-Coniacian sediments were deposited under oxidizing conditions. The supply of terrigenous material was cut off during the late Maestrichtian, and the upper Maestrichtian to upper Paleocene sequence is relatively pure nannofossil and foraminifer chalk. Sedimentation of the calcareous facies was continuous across the Cretaceous/Tertiary boundary, and benthic foraminifers indicate a depth of about 1000 meters at that time. The section includes 50 meters of Danian calcareous ooze. The Eocene was a time of important deposition of biogenic silica; surface water conditions were cool subtropical, as indicated by nannofossil, radiolarian, and foraminifer assemblages. Neogene sediments are almost entirely pelagic, because very little terrigenous sediment reached the site since the early Miocene. Major hiatuses span from late middle Eocene through Oligocene and late early Miocene through Pliocene. An inferred hiatus in the Campanian may be a local effect. The lowermost reflector, at $0.75 \mathrm{sec}$, seen as acoustic basement on most single channel reflection records on the plateau, corresponds to the top of the Albian limestones.

\section{Rio Grande Rise (Site 357)}

Site 357 was drilled and cored on the north flank of the Rio Grande Rise in order to complete the stratigraphic sequence partially sampled at Sites 21 and 22 (Maxwell, Von Herzen, et al., 1970), and to attempt to reach basement. A 797-meter sediment sequence was penetrated, and the hole bottomed in Santonian marly chalks; basement was not reached. The Santonian sediments are laminated, were deposited under partially reducing conditions, and also contain abundant terrigenous material. The terrigenous component and the reduced nature of the sediments decrease upsection. Oxygenated conditions began to dominate in the Campanian, and the terrigenous component drops off rapidly in the Maestrichtian and the Paleocene. Siliceous organisms are important only in the middle Eocene to lower Miocene nannofossil-foraminifer oozes. A volcanic-sedimentary breccia, 15 meters thick, is overlain and underlain by middle Eocene pelagic ooze. Shallow-water fossils, including red algae, and a uniform grading throughout the unit indicate it moved downslope from a very shallow water source in a single event. Lower Miocene through Pleistocene sediments are very pure nannofossil-foraminifer oozes.

We may use shallow-water sedimentary indicators of known age to speculate on the subsidence history of the Rio Grande Rise. The two depth-indicative findings from Leg 39 drilling are the Inoceramus fragments in the Santonian marlstones and the volcanic-sedimentary breccia in the middle Eocene. Thiede (in press; see discussion in Supko and Perch-Nielsen, this volume) uses these two data points, plus Oligocene oolitic limestone dredged by French colleagues and the basal Campanian (?) coquina at Site 21 , to construct a subsidence curve for the Rio Grande Rise. Such a curve indicates basement at Site 357 to be about 97 m.y. old and to lie 800 to 900 meters below the lowest core (see also discussion in McDowell et al., this volume, for geophysical evidence supporting a deep basement). Controversy still exists among the shipboard party on the applicability of a subsidence curve. Much rests on the depth significance of the Inoceramus fragments in the Santonian marly chalks. Thiede and Dinkelman (this volume) maintain that they are autochthonous and indicate water depths of 300 to 500 meters; Premoli-Silva and Boersma (this volume) believe that the depositional site was deeper and that the Inoceramus fragments were transported from upslope.

Inferred hiatuses occur in the mid-Campanian, at the Cretaceous/Tertiary boundary, the Paleocene/Eocene boundary, the Eocene/Oligocene boundary, and in the mid-Miocene and Plio-Pleistocene.

The 0.8 -sec reflector at Site 357 , which represents acoustic basement at this site and in many of the profile records shot over the Rio Grande Rise, correlates with the top of the well-indurated Santonian marls. 


\section{Argentine Basin (Site 358)}

We obtained only 16 widely spaced cores at Site 358 before being blown off the site. Although basement was not reached, the total penetration of 842 meters was sufficiently close to the calculated depth to basement $(897 \mathrm{~m})$ to allow extrapolating a basement age based on sediment accumulation rates. The lowermost core contained nannofossils of latest Campanian or earliest Maestrichtian age. Assuming the Late Cretaceous sediment accumulation rate was typical of the section between the lowest core and basement, and assuming basement is not a sill and no hiatus is present, we calculate a basement age of mid-Campanian, or about 74 m.y. for Site 358, located between anomalies 32 and 33. The isostatically adjusted depth of basement at Site 358 and basement age of 74 m.y. define a point which falls almost exactly on the empirical elevation curve for ocean crust defined by Sclater and Detrick (1973). Matching of correlative points on the South Atlantic magnetic anomaly profile and the magnetic stratigraphy of the well-dated (paleontologically) limestone section at Gubbio, Italy (Alvarez et al., in press) indicates an age range of 71.5 to 73 m.y. for Site 358 basement (Supko and Perch-Nielsen, this volume).

The last uphole occurrence of carbonate is at 730 meters, and is of middle Eocene age. Assuming normal crustal subsidence, a middle Eocene CCD of 4200 meters is indicated. The alternating marly chalks and mudstones in the section older than middle Eocene indicate that the deepening site was in the vicinity of the CCD for a long time. Boersma (this volume) uses faunal dissolution criteria to estimate the depth of the $\mathrm{CCD}$ at Site 358 from Maestrichtian to middle Eocene. The post-middle Eocene section at Site 358 consists of biosiliceous mudstones deposited at very high rates, except for short periods of slow sedimentation or actual hiatus across the Eocene-Oligocene boundary and in the middle Miocene. The silica occurs as frustules of diatoms and tests of radiolarians, except in the Eocene to middle Oligocene and in the middle Miocene, where the biogenic silica has been diagenetically altered to amorphous masses of silt-sized silica grains. We postulate that the diagenesis occurred at the sea floor at times of slow sediment accumulation, partially the result of periods of increased bottom current velocity.

Reflecting Horizon A at Site 358 correlates very well with a diagenetic change at 460 meters from biosiliceous mudstones of late Oligocene age to a facies of the same age in which the biogenic silica has been converted to amorphous masses. Horizon B corresponds to the facies change from biosiliceous mudstones to calcareous sediments at 730 meters.

\section{Walvis "Seamount" (Site 359)}

Site 359 was selected as a contingency site at the top of a feature in the southwestern, or "seamount" province of the Walvis Ridge. Bathymetry data acquired by Russian colleagues (see Neprochnov et al., this volume) subsequent to our drilling indicate that our site is on the southwesterly tip of a linear feature which strikes northeast and runs for an indeterminate distance. The Russian line shows the trend continuing to the southwest as individual seamounts.
The top sediments cored comprise Pleistocene to Miocene and upper Eocene foraminifer-nannofossil ooze. A major hiatus is present from upper Eocene to middle Miocene; portions of the Pliocene and Pleistocene are also missing. The biogenic oozes overlie 29 meters of calcareous volcanic mud, which in turn overly at least 10 meters of volcanic tuff, in which the hole bottomed. The tuff has a trachytic composition and is similar to ashflow tuffs on several Atlantic islands; on the basis of lack of graded bedding, lack of reworking by marine organisms, and lack of included shell material or clasts of marine sediment, we believe the tuff was deposited subaerially. A K/Ar date of 40.7 \pm 1 m.y.B.P. (late Eocene) was obtained on feldspars in the tuff (McKee and Fodor, this volume). The drill site sank below sea level just after the topmost ash was deposited, as indicated by the presence of both deepwater open marine and shallow-water benthic foraminifers in the calcareous volcanic mud. Igneous activity evidently ceased at about the same time, since the lowermost calcareous biogenic oozes contain no traces of volcanic products. The site is located at about the position of anomalies 23 to 25 (Ladd, 1974), which have age ranges of 47 to 53 m.y. according to Tarling and Mitchell (1976), or 54 to $59 \mathrm{~m} . \mathrm{y}$. according to La Brecque et al. (in press). We believe the feature formed as an island at the spreading center some 50 to 55 m.y. ago, spread eastward at about $2 \mathrm{~cm} /$ year, and finally sank below sea level about 40 m.y. ago. The upper Eocene volcanic ash indicates that the site carried with it an entrained magma chamber for 10 to 15 m.y. after it first formed.

\section{OPERATIONS SUMMARY}

Glomar Challenger departed Amsterdam at 2030 on 6 October 1974 and arrived in Cape Town at first light on 17 December 1974, for a total cruise length of 72 days; a one-day port call was made on 5-6 November to change Global Marine crews and a part of the scientific party.

Glomar Challenger traveled 9895 miles and drilled 11 holes on seven sites in water depths from 1668 to 5177 meters. Total penetration was 4231 meters; 135 cores were taken, representing total recovery of 1175 meters. Coring data are listed in Table 1.

Time distribution for the leg was 12.1 days in port (for record purposes, the official starting date for Leg 39 was 25 September 1974, which includes a drydocking period before the cruise), 43.2 days cruising, and 27.3 days on-site (Figure 4). The on-site time consisted of 5.9 days pulling pipe, 5.9 days drilling, 12.6 days coring, 1.0 days positioning ship, 1.2 days mechanical downtime, and 0.8 days miscellaneous time (Figure 5).

This leg had its share of operational successes and failures to add to the project experience. The 90 -foot piccolo, designed to provide lateral support to the drill string in and below the moon pool, to minimize bending of the string from vessel roll and pitch, was successfully installed. Handling the 60 -foot section was easier than expected. The Bowen power sub failed and was replaced with the new power sub, with a time loss of one-half day. The heave compensator leaked hydraulic fluid from the top vent and the lower seals each time it was installed. It did function on the first 


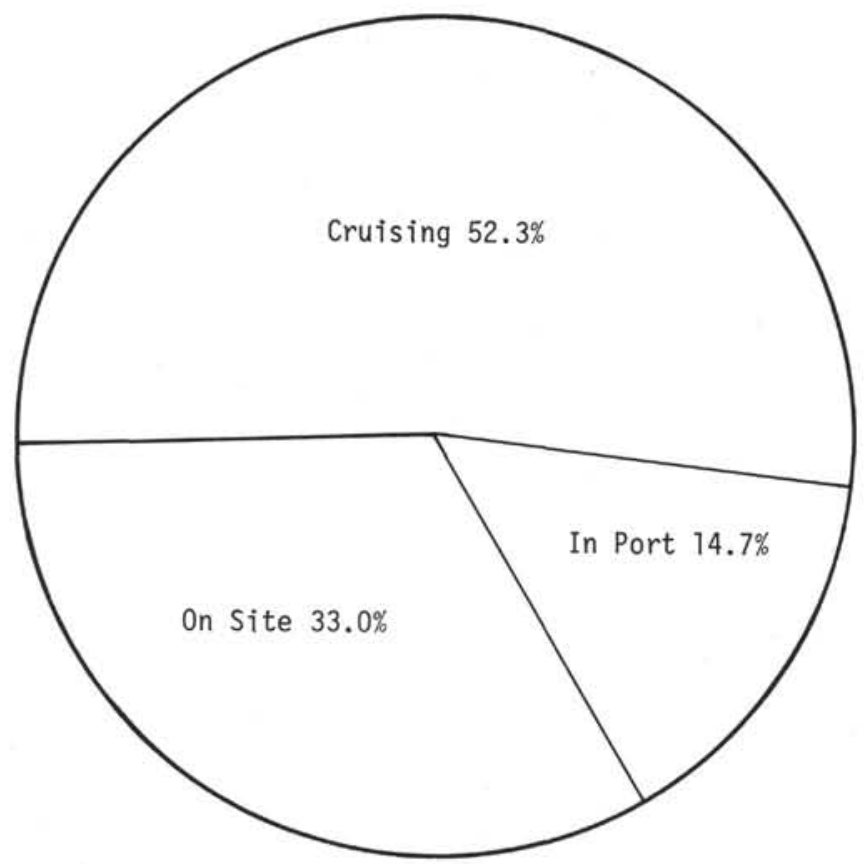

Figure 4. Total time distribution, Leg 39.

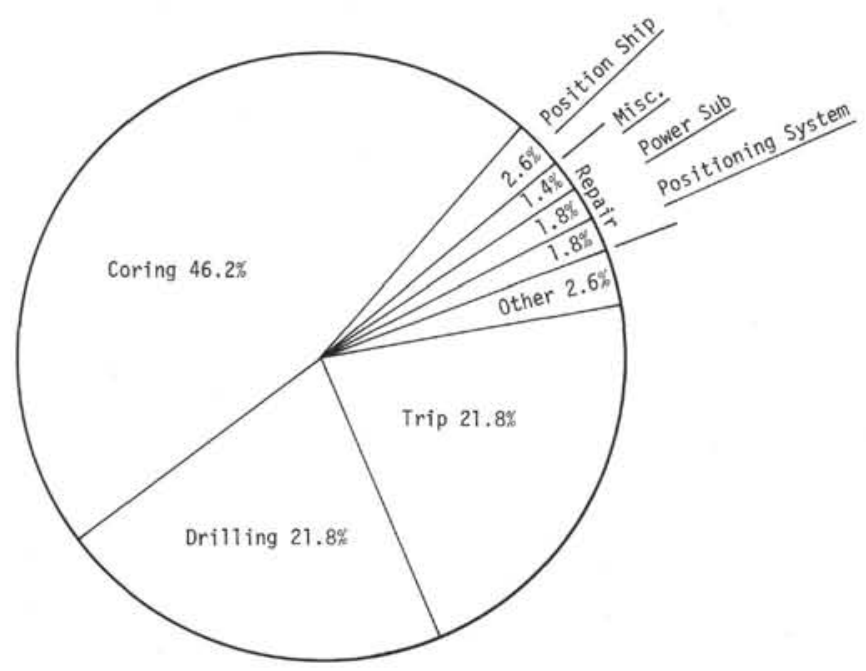

Figure 5. On-site time distribution, Leg 39.

half of the leg, but the crew on the last half of the leg was unable to operate it. The dynamic positioning system logged 12 hours downtime. Most of the problems were in the computer.

The bottom-hole assembly used on all sites was as follows: bits, core barrel, three 8-1/4-inch drill collars, one Baash Ross bumper sub, three 8-1/4-inch drill collars, two Baash Ross bumper subs, two 8-1/14-inch drill collars, one 7-1/4-inch drill collar, one joint 5-1/2inch heavy weight drill pipe. The Smith F94CK bit used on all sites was the best compromise between penetration rate in the softer sediments and endurance in the chert or basalt expected at all sites. Only the first bit showed any wear, and this was gauge wear from rotating in sloughing basalt rubble.

Core recovery was good, as shown by the overall average of $69 \%$. A 1.1-meter section of basalt core dropped through the core catcher during core retrieval on Site 354 and plugged the drill pipe near the surface; the hole was abandoned.

The pinger piston corer was run on the first site, but the pinger failed before reaching the mudline. The inner core barrel stuck, and two wireline runs were required to retrieve it. Core recovery was 0.01 meters. The pinger transducer was damaged beyond field repair, and the entire tool was set aside. A spare transducer was not available.

Problems with the positioning system accounted for 12 hours downtime on Sites 354,355, and 359. At some of the other sites we had minor equipment problems, which were solved without loss of time.

On Site 354, six hours downtime were logged for initial positioning problems. Positioning over the beacon was complicated by $40 \mathrm{mph}$ east-by-northeast winds and a three-knot south-by-southwest current, which taxed the expertise of the marine crew and exacerbated positioning-system problems. Switching tachometer generators on the bow thrusters and setting exciter feedbacks solved the equipment problems. Shifting winds occasionally caused excursions of 160 feet, and a maximum error of 300 feet on 28 October.

Five hours downtime for positioning on Site 355 was caused by faulty hydrophone pre-amps and a bad D/A power regulator. Maximum excursion was 120 feet.

At Site 359 we logged only one hour of downtime, but more than 12 hours would have been lost had the bottom-hole assembly inspection and the trip in been delayed until accurate positioning was established. A second beacon was dropped after troubleshooting for six hours, but the erratic display, with apparent rapid excursions to 3000 feet, remained. The display problem finally reduced to a short oscillation in phase with ship's roll, and the hole was spudded.

The on-site weather, except on the last day on Site 358 , was ideal, and we recorded a mean positioning error of 35 feet for the leg. Except for Site 354, at which we had a three-knot current to stem, the positioning system generally was operated at less than half speed.

Persons interested in a more detailed account of operational aspects of Leg 39 are advised that report number 8, "Operations Resumés, Legs 34 through $44 \mathrm{~A}$ " is available from National Technical Information Services, 5259 Port Royal Road, Springfield, Virginia 22151, USA (Order \# PB253036, \$11.75, microfiche $\$ 2.25$ ).

\section{Uncertainty About Core Depths}

Users of DSDP samples and data should be cautioned that the depth at which a core or part of a core was collected is sometimes uncertain when the section was not continuously cored. This problem is not unique to Leg 39 , but other scientific teams on board Glomar Challenger seem to be unaware of the problem or tend to ignore it.

Two techniques may be used to penetrate a sediment section without taking a core. One is to drop a center bit, thus presenting a solid cutting face to the sediment and eroding it totally away. This is time-consuming, in terms of both the round-trip time required to drop and retrieve the center bit and the slow drilling rate with a 
center bit in place. Consequently, the center bit is seldom used. The second technique is to drill with the open core barrel in place, using high pump pressure to prevent sediment from entering the core barrel. When the desired depth interval is reached, pump pressure is reduced and a core is cut and retrieved. In sediments only slightly consolidated, this technique is quite effective, and it is safe to assume that the core was collected in the desired interval. In more consolidated sections, the pump action is less effective, or ineffective, in "washing away" the sediment, and core is inadvertently collected in the drilled interval. This was proved on Leg 39 when we drilled a 38-meter interval with full pressure, trying not to take a core; when we pulled the core barrel, it was full (see Operations, Site 354). In such cases, the core may have come from anywhere within the drilled interval; indeed, in more compact sediments it more probably represents the top of the interval. In compact sediment, the uncertainty is minimized by cutting the core at the top of a coredplus-drilled interval and drilling the remaining interval with the full core barrel, essentially using the core itself as a center bit. There is some danger here too, in that recovery may not have been total in the top 9.5 meters, i.e., some of the lower part of the core may have been collected in the drilled interval. We also found, when using this technique on Leg 39, that a lithologic change or paleontological boundary would often be represented by a small piece of sediment at the base of the core-catcher sample, i.e., sediment different from the rest of the core. This almost certainly does not represent a real geologic change at 9.5 meters down in the cored-plus-drilled section. Rather, the core barrel was probably filled in the top 9.5 meters, and as the remaining section was then drilled, the very bottom of the core catcher picked up a small additional sample in the drilled interval (most probably at the bottom).

In those cases on Leg 39 where we have reason to suspect that one of these processes has occurred, we discuss it in either the Operations or Sediment Accumulation Rates sections of the site report.

\section{EXPLANATORY NOTES}

\section{Site Reports}

Certain conventions were used when collecting basic data at sea. Water depth may be based either on drill pipe measurement or on PDR measurement, corrected using Matthews' tables. In general, if the driller encountered a firm bottom contact at a measured depth less than the PDR depth, the drill pipe measurement was accepted. If the bottom was soft and the PDR depth was less than the drill pipe measurement, the PDR depth was accepted. Method of determination of water depth is indicated for each site. Subbottom depths are all by drill pipe measurement.

Sedimentation rates are more in reality sediment accumulation rates, a net sum of all depositional and erosive processes, uncorrected for compaction.

Changes or breaks in drilling rate are sometimes useful in helping to pick unit boundaries in sections not continuously cored. Where used, they are indicated in the site report. Drilling rates are only plotted at Sites
356,357 , and 358 , where they are particularly diagnostic for interpreting the sediment section.

\section{Authorship}

The authorship of the site report chapters is the responsibility of the entire scientific party, with final responsibility of the co-chief scientists, who rewrote all site chapters prior to publication. Note that the scientific party partially changed after Site 354 . In general, original authorships were as follows:

-Background and Objectives (Supko; Kumar, 356; Thiede, 357)

-Operations (Supko)

-Lithology (McCoy, 353, 355; Zimmerman, 354, 358; Kumar, 356; Thiede, 357, 359)

-Igneous Petrology (Bonatti, 353, 354; Fodor, 355, $356,357,359$ )

-Geochemistry (Supko) 354)

-Physical Properties (Carlson; Neprochnov, 353,

-Biostratigraphic Summary (Perch-Nielsen, 353, 354, 355, 358; Boersma, 356, 357, 359)

Foraminifers-Boersma

Nannofossils-Perch-Nielsen

Radiolaria-Dinkelman ${ }^{2}$ studies

Diatoms and Palynology-taken from shore-lab

- Sediment Accumulation Rates (Perch-Nielsen)

-Correlation of Reflecting Horizons with the Stratigraphic Section (Supko; Kumar, 356)

-Summary and Conclusions (Supko and PerchNielsen; Kumar, 356; Thiede, 357; Zimmerman, 358)

\section{Numbering of Sites, Holes, Cores, Samples}

Drill site numbers run consecutively from the first site drilled by Glomar Challenger in 1968, so the site number is unique. A site refers to the hole or holes drilled from one acoustic positioning beacon. Several holes may be drilled at a single location by pulling the drill string above the sea floor ("mud line") and offsetting the ship some distance (usually $100 \mathrm{~m}$ or more) from the previous hole.

The first (or only) hole drilled at a site takes the site number. Additional holes at the same site are further distinguished by a letter suffix. The first hole takes only the site number; the second takes the site number with suffix $A$; the third takes the site number with suffix $B$; and so forth. It is important, for sampling purposes, to distinguish the holes drilled at a site, since recovered sediments or rocks usually do not come from equivalent positions in the stratigraphic column at different holes.

Cores are numbered sequentially from the top down. In the ideal case, they consist of 9 meters of sediment or rock in a plastic liner of $6.6 \mathrm{~cm}$ diameter. In addition, a short sample is obtained from the core catcher (a multifingered device at the bottom of the core barrel which prevents cored materials from sliding out during corebarrel recovery). This usually amounts to about $20 \mathrm{~cm}$

\footnotetext{
${ }^{2}$ Paper not received in time for inclusion in this volume.
} 
of sediment and is stored separately. This sample, from each core, represents the lowest stratum recovered in the particular cored interval. The core-catcher sample is designated by CC (e.g., 358-4, CC, core-catcher sample of the fourth core taken at Site 358).

The cored interval is the interval in meters below the sea floor, measured from the point at which coring for a particular core was started to the point at which it was terminated. This interval is generally 9.5 meters (nominal length of a core barrel), but may be shorter if conditions dictate. Cores and cored intervals need not be contiguous. In soft sediments, the drill string can be "washed ahead" without recovering core by applying sufficiently high pump pressure to wash sediment out of the way of the bit. In a similar manner, a center bit, which fills the opening in the bit face, can replace the core barrel if drilling ahead without coring is necessary. See further discussion and cautionary notes under "Operations Summary."

When a core is brought aboard Glomar Challenger, it is labeled, and the plastic liner and core are cut into 1.5meter sections. A full, 9-meter core would thus consist of six sections, numbered from the top down, 1 to 6 . (The discrepancy between the 9-m core and 9.5-m cored interval is discussed below.) Generally something less than 9 meters is recovered. In this case, the sections are still numbered starting with one at the top, but the number of sections is the number of 1.5-meter intervals needed to accommodate the length of core recovered; this is illustrated in Figure 6.

Thus, as shown, recovery of 3.6 meters of sediment would result in a core with three sections, with a void of 0.9 meters at the top of the first section (Figure 7). By convention, and for convenience in routine data handling at the Deep Sea Drilling Project, if a core contains a length of material less than the length of the cored interval, the recovered material is placed in the top of the cored interval, with the top of Section 1, rather than the top of the sediment, equal to the top of the cored interval. This is shown below for the core in the above sample.

Thus the depth below the sea floor of the top of the sediment of this hypothetical core would lie at 150.9 meters (not $150.0 \mathrm{~m}$ ) and the bottom at 154.5 meters (the core-catcher sample is regarded as being dimensionless).

It was noted above that a discrepancy exists between the usual coring interval of 9.5 meters and the 9-meter length of core recovered. The core liners used are actually 9.28 meters in length, and the core catcher

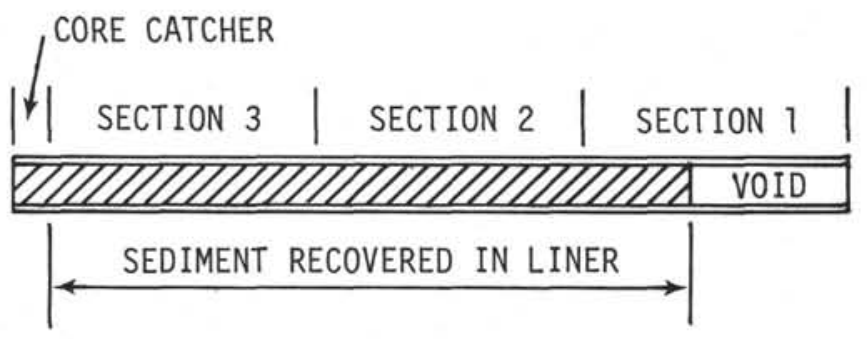

Figure 6. DSDP core labeling conventions.

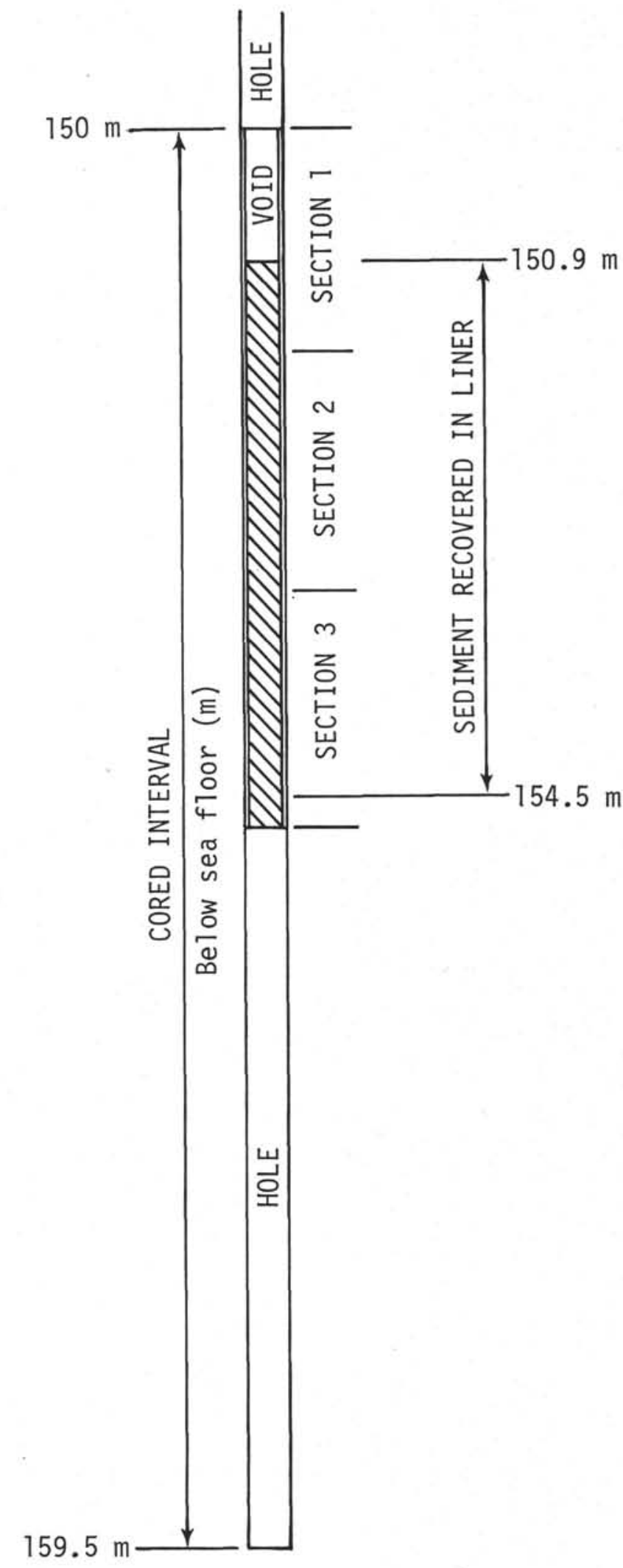

Figure 7. DSDP core depth conventions.

accounts for another 0.2 meters. In cases where the core liner is recovered full to the top, the core is still cut into six 1.5-meter sections, measured from the bottom of the 
liner, and the extra 0.28 -meter section at the top is designated Section 0, or the "zero section." The zero section is ignored in calculations of depth below the sea floor of cores or levels within cores.

In the core laboratory on Glomar Challenger, after routine processing, the 1.5-meter sections of sediment core and liner are split in half lengthwise. One half is designated the "archive" half, which is described by the shipboard geologists, and photographed; and the other is the "working" half, which is sampled by the shipboard sedimentologists and paleontologists for further shipboard and shore-based analysis.

Basalts are not split in this manner. Rather, small mini-cores are taken using a drill press and a small diamond-studded coring device. The mini-cores are subsequently divided for specific sampling needs. For additional details regarding the shipboard handling of basalt, contact the Curator, Deep Sea Drilling Project.

Samples taken from core sections are designated by the interval in centimeters from the top of the core section from which the sample was extracted; the sample size, in cc, is also given. Thus, a full sample designation would consist of the following information:

Leg (optional)

Site (hole, if other than first hole)

Core number

Section number

Interval in centimeters from top of section

Site 353A-1-2, 122-124 cm (10 cc) designates a 10-cc sample taken from Section 2 of Core 1 from the second hole drilled at Site 353. The depth below the sea floor for this sample would then be the depth to the top of the cored interval ( $150 \mathrm{~m}$ in the example above), plus 3 meters for Sections 1 and 2, plus $122 \mathrm{~cm}$ (depth below the top of Section 3), or 154.2 meters. (Note, however, that sample requests should refer to a specific interval within a core section [in centimeters] rather than level [m] below sea floor.)

\section{Core Handling}

The first assessment of the core material was made on samples from the core catcher. An age by paleontology enabled decisions to be made on whether to drill ahead or to take another core.

After a core section had been cut, sealed, and labeled, it was brought into the core laboratory for processing. The routing procedure listed below was usually followed:

1) weighing of the core section for mean bulk density measurement;

2) GRAPE analysis for bulk density;

3) sonic velocity determinations; and

4) thermal conductivity measurements.

After the physical measurements were made, the core liner was cut, and the core split into halves by a wire cutter, if the sediment was a soft ooze. If compacted or partially lithified sediments were included, the core was split by a machine band saw or diamond wheel.

One of the split halves was designated a working half. Samples, including those for grain size, X-ray mineralogy, interstitial water chemistry, and total carbon, organic carbon, and carbonate content were taken, labeled, and sealed. Larger samples were taken from suitable cores for organic geochemical analysis, usually prior to splitting the core. The working half was then sent to the paleontology laboratory. There, samples for shipboard and shore-based studies of microfossil groups were taken.

The other half of a split section was designated an archive half. The cut surface was smoothed with a spatula to emphasize the sedimentary features. The color, texture, structure, and composition of the various lithologic units within a section were described on standard visual core description sheets (one per section), and any unusual features noted. A smear slide was made, usually at $75 \mathrm{~cm}$ if the core was uniform. However, two or more smear slides were often made, one for each area of distinct lithology in the core section. The archive half of the core section was then photographed. Both halves were sent to cold storage on board ship after they had been processed.

Material obtained from core catchers, and not used up in the initial examination, was retained in freezer boxes for subsequent work. Sometimes significant pebbles from the core were extracted and stored separately in labeled containers. On other occasions, the liners would contain only sediment-laden water. This was usually collected in a bucket and allowed to settle, and the residue was stored in freezer boxes.

At several sites, cores of either basement or indurated sediment were obtained. Each separate core fragment was numbered and labeled consecutively from the top downward and its orientation indicated by an upwardpointing arrow. Where possible, the fragments were arranged into their original relative orientation and were then sliced longitudinally for examination and separation into working and archive halves.

All samples are now deposited in cold storage at the East Coast Repository at Lamont-Doherty Geological Observatory, and are available to investigators.

\section{Core Disturbance}

The rotary drill-coring technique quite often results in a high degree of disturbance of the cored sediments. This is especially true of the softer unconsolidated sediments. A qualitative estimate of the degree of deformation is given on the core logs.

\section{Carbon-Carbonate Data}

Sediment samples are analyzed on a Leco 70-Second Analyzer at DSDP; procedures are described by Scott and Thompson (this volume). Accuracy and precision of the results are as follows:

$$
\begin{array}{ll}
\text { Total carbon } & \pm 0.3 \% \text { (absolute) } \\
\text { Organic carbon } & \pm 0.06 \% \text { (absolute) } \\
\mathrm{CaCO}_{3} & \pm 3 \% \text { (absolute) }
\end{array}
$$

Additional carbonate data has been obtained on board Glomar Challenger by the carbonate bomb method (Müller and Gastner, 1974), in the laboratory facilities of the School of Oceanography of Oregon State University (Leco) and of the Institute of Oceanology of the Soviet Academy of Sciences 
(Emelyanov and Trimonis, this volume). The DSDP data are listed on the core forms. All data have been tabulated together as appendices to the site reports.

\section{Grain Size Analyses}

The DSDP grain size analysis presented on the core logs were performed by standard sieve and pipette techniques, described in Scott and Thompson (this volume).

\section{Sediment Classification}

The sediment classification used here was devised by the JOIDES Panel on Sedimentary Petrology and Physical Properties, and adopted for use by the JOIDES Planning Committee in March, 1974. It appears as an appendix to this chapter.

Accompanying the sediment classification is a set of lithologic symbols. These symbols have been used on all core and site summary forms.

\section{Smear Slides}

Smear slides are the basic means of shipboard mineral identification, although thin sections and mineral grain mounts are used in studies of basaltic rocks.

Smear-slide estimates of mineral abundances were based on the area of the smear slide covered by each component. Past experience has shown that accuracy may approach a percent or so for very distinctive minor constituents, but for major constituents, accuracy of $\pm 10 \%$ to $20 \%$ is considered very good. Relative changes in component abundances are more important to the geologist than absolute accuracy.

\section{Core Forms}

The basic lithologic data are contained on core summary forms. As far as possible the data are presented in the following order:

Sediment or rock name

Sediment disturbance and sedimentary structures

Color name and Munsell or GSA number

Colors recorded in core barrel summaries were determined during shipboard examination immediately after splitting core sections. Experience with carbonate sediments shows that many of the colors will fade or disappear with time after opening and storage. Colors particularly susceptible to rapid fading are purple, light and medium tints of blue, light bluish gray, dark greenish black, light tints of green, and pale tints of orange. These colors change to white or yellowish white or pale tan.

Composition via smear slides

Grain size and carbon-carbonate data

Many cores contain important minor lithologies as well as a basic lithology. The description of the basic lithology is so indicated in most cases, but descriptive information for minor lithologies is included wherever possible.

A sample core form precedes the site-by-site presentation of the cores. This sample core form contains all legend and explanatory notes needed for an understanding of the core forms.

\section{Basis for Age Determination}

Planktonic foraminifers, calcareous nannofossils, radiolarians, and, to a lesser extent, palynomorphs, diatoms, and silicoflagellates, were used to determine the ages of sediments cored on Leg 39. For the Cenozoic, the time scale of Berggren (1972) was used to translate foraminifer-coccolith- and radiolarian zones into age. Where correlations between foraminifer and coccolith zones differed from those suggested by Berggren (1972), an age was assigned according to the fossil group that seemed most reliable in the particular sequence. For details see the site chapters.

\section{Planktonic Foraminifers}

The Cretaceous was divided according to the zonation of Premoli-Silva and Bolli (1973). For the Tertiary, basically the zonation in Berggren (1972) was followed except where no longer applicable because of recent revisions and unpublished corrections (i.e., Pliocene).

\section{Calcareous Nannofossils}

The coccolith zones used in this report for the Tertiary follow mainly the "standard calcareous nannoplankton zonation" proposed by Martini (1971). In some sequences, the sometimes finer, sometimes coarser zonation suggested by Bukry (1973) could be or had to be applied. For the zonation of the Cretaceous, essentially the zonal markers proposed by Thierstein (1975) were used.

\section{Radiolaria}

In general, the standard radiolarian zonation as recently revised and more precisely defined by Riedel and Sanfilippo (in press) was utilized in this report. An exception to this is Site 358 in the Argentine Basin, where the mixed nature of the assemblages, with elements from both high and low latitudes, precluded direct usage of the standard zonation. For this site, the zonation of Chen (1975) was used in conjunction with the one of Riedel and Sanfilippo.

\section{Diatoms, Silicoflagellates, and Palynomorphs}

Age assignments and the basis of age assignments using these fossil groups are discussed in the relevant site report chapters and specific chapters.

\section{Physical Properties}

Certain physical properties are measured aboard ship to aid interpretation of geophysical surveys taken before and after occupying the site, and because many of these properties, such as acoustic velocity, water content, and even porosity, change with time after sample recovery. Consequently, this section serves primarily as a summary of shipboard techniques. Independently measured properties are sonic velocity, density, and water content. Porosity and acoustic impedance are computed. 


\section{Density and Porosity Measurements}

Several methods are commonly used to estimate wet bulk density on ship: values may be determined from the weights and dimensions of right cylindrical samples, by immersion, or by using the Gamma Ray Attenuation Porosity Evaluator (GRAPE).

Gravimetric methods for determining density require accurate measurement of sample weights and/or volumes, both of which can be extremely difficult on ship. It has been suggested that samples may be weighed to within $\pm 0.05 \%$ by setting the knife edge of the triple-beam balance parallel to the axis of the ship and making measurements only while stabilized for drilling.

Practical experience on shore and at sea has shown, however, that water evaporates from samples during weighing in air, and the samples often degrade during immersion measurements. Because of the ship's motion, the weighing process can be lengthy, and either or both of these problems can become significant. Therefore, densities estimated in this way are in practice accurate to within about $2 \%$. The syringe technique, designed to facilitate sampling of soft sediments, is a variation of the mass-volume method. Sampling is accomplished by carefully pressing the syringe into the core. A measured length of the sample is then weighed to determine the mass. Volumes of soft sediment must be estimated from the inside dimensions of the syringes. Since considerable errors may arise in determining these volumes (Bennett and Keller, 1973), and there may be significant distortion of the sediments in drilling and sampling, measured values of wet bulk density must be regarded as approximations $( \pm 5 \%)$ to those in situ. Sediment porosity can also be estimated from syringe samples. Because the sample volume is known and the pore volume can be estimated from the weight of water lost by drying, porosity can be directly computed. Clearly, porosity determinations are subject to the same difficulties as the computed densities, and the magnitude of the error is about the same, or slightly greater. The only major disadvantage of the syringe sampling method is that it cannot be used for stiff sediments. When the syringe method fails, chunks of material are removed from the core in order to determine water content.

The GRAPE (Gamma Ray Attenuation Porosity Evaluator) technique may be applied in either of two ways: a continuous mode in which entire sections are scanned, and a static mode in which the attenuation of the beam through a particular sample is measured for a period of two minutes. In either case, the apparent density of the attenuating medium is

$$
\rho_{b}=\frac{\ln \left(I_{o} / I\right)}{\mu \ell}
$$

where

$$
\begin{aligned}
\rho_{b} & =\text { apparent bulk density }(\mathrm{g} / \mathrm{cc}) \\
I_{O} & =\text { intensity of unattenuated beam (counts) } \\
I & =\text { intensity of attenuated beam (counts) } \\
\mu & =\text { attenuation coefficient for the material in } \\
\ell & =\text { question, } \\
\ell & \text { path length }(\mathrm{cm}) \text { (see Boyce, 1973). }
\end{aligned}
$$

Throughout Leg 39, we used the static mode to estimate densities of samples cut from the working half of the core. When it was necessary to store the samples for several hours before the measurements, they were wrapped in plastic and refrigerated to prevent dehydration. The first step in the measurement process was a set of three two-minute counts through air to establish $I_{o}$. Next, a set of up to ten samples was tested, also by taking three two-minute counts. Finally, attenuation through a $6.6-\mathrm{cm}$ cylindrical aluminum standard was measured to complete the cycle. The accuracy of the two-minute GRAPE method is $\pm 2 \%$ (Boyce, 1973), and the errors observed in the aluminum standard measurements are well within these limits. It must be pointed out, however, that GRAPE densities tend to be slightly higher than densities determined by the immersion or syringe methods.

Porosity can be computed directly from syringe data, as described above. It can be estimated from immersion and GRAPE data only by assuming reasonable values for the grain density of the sample, and the density of the pore fluid (sea water). Then,

$$
\phi=\frac{\rho_{g}-\rho_{b}}{\rho_{g}-\rho_{f}}
$$

where

$\phi=$ porosity,

$\rho_{b}=$ bulk density,

$\rho_{g}=$ grain density,

$\rho_{g}=$ fluid density, $(1.025 \mathrm{~g} / \mathrm{cc}$, sea water $)$.

Virtually all of the sediments recovered on Leg 39 are highly calcareous; a reasonable choice for $\rho_{g}$ is thus 2.7 $\mathrm{g} / \mathrm{cc}$.

\section{Sonic Velocity Measurements}

Sonic velocities are routinely measured aboard ship with a Hamilton frame velocimeter. This method involves measurement of the transmission time through the sample of a $400 \mathrm{MHz}$ pulse by using oscilloscope delay circuitry. Because the thickness of the sample is determined simultaneously, the velocity is easily computed. The method may be applied to samples cut from the core, or the measurements may be made at selected points on the split core itself. In the latter case, a correction must be made for the sonic velocity and thickness of the core liner. Moreover, there is often a slurry of mud between the liner and the core, which significantly reduces the accuracy of split-core measurements. Therefore, most velocity measurements were made on samples cut from the cores. After Site 354 , this practice was employed exclusively. Standard measurements show that the Hamilton Frame velocities are commonly repeatable to within $1 \%$. The chief limitation of the technique is that sonic velocities depend strongly on confining pressures (e.g., Birch, 1960; Christensen, 1970). Thus the measured values do not necessarily apply at conditions in situ, and these data must be used with caution.

The measurement of time delay by electronic circuitry was found to have a number of drawbacks in normal operation of the Hamilton Frame at Sites 353 and 354 . The chief difficulties observed were the noise 
and instability of signals, and the rather cumbersome process of making two length and two time measurements for each velocity determination. Each of these problems makes error more likely. The long steaming time between Sites 354 and 355 provided the opportunity to set up a fluid delay line, as described by Birch (1960) and Christensen (1970).

The delay line method involves splitting the output pulse from the signal generator: on one side of the circuit the signal is transmitted through the sample, and on the other side the pulse is transmitted through a fluid column of variable length. Output signals from the sample and the delay column are then displayed on separate channels of the scope, and the length of the delay is adjusted until the initial rise from the delay line and that from the sample are matched. At this point, the lengths of the sample $\left(l_{s}\right)$ and the fluid column $\left(l_{f}\right)$ are recorded. The velocity of the sample is then computed using the known velocity of the fluid $\left(V_{f}\right)$ :

$$
V_{s}=\frac{1_{s} V_{f}}{1_{f}}
$$

At Site 355, the application of fluid delay line for the measurement of sonic velocities was tested for the first time with the Hamilton Frame. A distilled water delay column was constructed by bonding a plastic container to the base of the Hamilton Frame and filling it with distilled water. A second set of transducers was attached to the ram penetrometer frame, which was adapted for sample measurement.

One obvious calibration problem is that $V_{f}$ must be well known. To accomplish this measurement the Hamilton Frame was used in the conventional way. Starting at zero transducer separation, time delays were recorded for successively larger separations of the transducers in the water column. The velocity of the distilled water was then determined by the least-squares method.

Normally, such a procedure fits an equation of the form $x=a+v t$ to the data. Since $a$ and $v$ are unknown, the solution involves two equations and generates two finite coefficients. However, the delay time for zero separation should be zero, and the equation simplifies to $x=v t$. In this case, the equations were solved for $a=$ $o$ and for a variable. In each case the calculated value for $v$ was $1.4928 \mathrm{~km} / \mathrm{sec}$.

A second calibration problem derives from the fact that the transducers in this system were capped by epoxy buffers. Without the buffers, there would be no delay at zero separation. Similarly, the buffers would have no effect if the buffer delay were the same in both columns. In this case, however, the buffer delays were unequal, and the difference must be accounted for either mechanically or by computation. Fortunately, the buffer delay through the water column was slightly less than that through the sample side of the system, so the reference times could be set equal simply by setting the reference length of the water column with a slight separation.

During normal operations at Site 355, velocities were measured simultaneously by the delay line method and by the conventional technique outlined in the velocimeter manual. The purpose of these dual measurements was to compare results and test the ease of operation of the delay line system. The least accurate link in the system was found to be the measurement of length on the dial micrometer of the penetrometer frame, which may be read to only about $0.025 \mathrm{~mm}$. Otherwise, the experiment was highly successful. Signals were clean, stable, and easily matched. The delay line determinations also proved remarkably accurate. The results of five calibration tests made at different times show that the average error for the delay line method was $0.68 \%$ (range: 0.15 to 0.91 ) as opposed to $1.52 \%$ for the conventional method (range: 1.31 to 1.71). Average errors of less than $1 \%$ are remarkably small for shipboard measurements made quickly.

\section{Acoustic Impedance}

Acoustic impedance, $Z$, is the product of sonic velocity and density, $\rho v$, presented in units of gram $\mathrm{sec}^{-1} \mathrm{~cm}^{-2} \times 10^{-5}$. As for porosity, acoustic impedances computed from syringe, immersion, and GRAPE densities are separately listed in the site chapters.

\section{Geochemical Measurements}

Aboard ship, analyses for $p \mathrm{H}$, alkalinity, and salinity are conducted routinely.

1) $p \mathrm{H}: p \mathrm{H}$ is determined by two different methods. One is a flow-through electrode method, the other is a punch-in electrode method. $p \mathrm{H}$ is determined on all samples by the flow-through method, which uses a glass capillary electrode in which a small portion of unfiltered pore water is passed. In the softer sediments, a "punch-in" $p \mathrm{H}$ is also determined by inserting $p \mathrm{H}$ electrodes directly into the sediment at ambient temperature prior to squeezing. The $p \mathrm{H}$ electrodes for both methods are plugged into an Irion digital millivolt meter.

2) Alkalinity: Alkalinity is measured by colorimetric titration of a $1-\mathrm{ml}$ aliquot of interstitial water with $0.1 \mathrm{~N}$ $\mathrm{HCl}$, using a methyl red/blue indicator.

$$
\text { Alkalinity }(\mathrm{meq} / \mathrm{kg})=\mathrm{ml} \mathrm{HCl} \text { titrated } \cdot 97.752
$$

3) Salinity: Salinity is calculated from the fluid refractive index as measured by a Goldberg optical refractometer, using the ratio:

$$
\text { Salinity }(\% 00)=0.55 \Delta N
$$

where $\Delta N=$ refractive index difference $\times 10^{4}$. Local surface sea water is regularly examined by each of the above methods for reference.

\section{Underway Geophysics}

The survey data used for specific site selections are given in each site report chapter. On passage between sites, continuous observations were made of depth, magnetic field, and subbottom structure. Short surveys were made on Glomar Challenger before dropping the beacon, using a precision echo sounder, seismic profiles, and magnetometer. 
Underway depths were continuously recorded on a precision graphic recorder (PGR). The depths were read on the basis of an assumed 800 fathoms/sec sounding velocity. The sea depth (in $\mathrm{m}$ ) was corrected (1) according to the tables of Matthews (1939) and (2) for the depth of the hull transducer below sea level (6 $\mathrm{m})$.

The seismic profiling system consisted of two Bolt airguns, a Scripps-designed hydrophone array, Bolt amplifiers with two bandpass filters, and two EDO recorders, usually recording at two different filter settings. Underway data are presented in Neprochnov et al. (this volume).

\section{REFERENCES}

Alvarez, W., Arthur, M.A., Fischer, A.G., Lowrie, W., Napoleone, G., Premoli-Silva, I., and Roggenthen, W., in press. Late Cretaceous-Paleocene geomagnetic reversal time scale: type section in the pelagic limestone sequence at Gubbio, Italy: Geol. Soc. Am. Bull.

Bader, R.G., Gerard, R., et al., 1970. Initial Reports of the Deep Sea Drilling Project, Volume 4: Washington (U.S. Government Printing Office).

Bennett, R.H. and Keller, G.H., 1973. Physical properties evaluation. In van Andel, T.H., Heath, G.R., et al., Initial Reports of the Deep Sea Drilling Project, Volume 16: Washington (U.S. Government Printing Office), p. 513520.

Berggren, W.A., 1972. A Cenozoic time-scale: implications for regional paleogeography and paleobiogeography: Lethaia, v. 5, p. 195-215.

Birch, F., 1960. Velocity of compressional waves in rocks to 10 kilobars: J. Geophy. Res., v. 65, p. 1083.

Bolli, H., Ryan, W.B.F., Foresman, J.B., Hottman, W.E., Kagami, H., Longoria, J.F., McKnight, B.K., Melguen, M., Natland, J., Proto-Decima, F., and Siesser, W.G., 1975. Basins and margins of the eastern South Atlantic: Geotimes, v. 20, p. 22-24.

Boyce, R.E., 1973. Physical properties methods. In Edgar, N.T., Saunders, J.B., et al., Initial Reports of the Deep Sea Drilling Project, Volume 15: Washington (U.S. Government Printing Office), p. 1115-1128.

Bukry, D., 1973. Low-latitude coccolith biostratigraphic zonation. In Edgar, N.T., Saunders, J.B., et al., Initial Reports of the Deep Sea Drilling Project, Volume 15: Washington (U.S. Government Printing Office), p. 685703.

Chen, P-H., 1975. Antarctic Radiolaria. In Hayes, D.E., Frakes, L.A., et al., Initial Reports of the Deep Sea Drilling Project, Volume 28: Washington (U.S. Government Printing Office), p. 437-513.

Christensen, N., 1970. Compressional wave velocities in basalts from the Juan de Fuca Ridge, J. Geophys. Res., v. 75 , p. 2773.

Gealy, E.L., Winterer, E.L., and Moberly, R., 1971. Methods, conventions and general observations, Initial Reports of the Deep Sea Drilling Project, Volume 7: Washington (U.S. Government Printing Office), p. 9-26 (p. 17 contains carbonate lithification definitions).

La Brecque, J., Kemp, D., and Cande, S., in press. Reversal magnetic polarity time scale for the Late Cretaceous and Cenozoic: submitted to Geology.
Ladd, J.W., 1974. South Atlantic sea floor spreading and Caribbean tectonics: Ph.D. thesis, Columbia University, New York.

Lancelot, Y., Seibold, E., Cepek, P., Dean, W., Eremeev, V., Gardner, J.V., Jansa, L.F., Johnson, D., Krasheninnikov, V., Pflaumann, U., Rankin, J.G., and Trabant, P., 1975. The eastern North Atlantic: Geotimes, v. 20, p. $18-21$.

Le Pichon, X. and Fox, P.J., 1971. Marginal offsets, fracture zones and the early opening of the North Atlantic: J. Geophys. Res., v. 76, p. 6294-6308.

Le Pichon, X. and Hayes, D.E., 1971. Marginal offsets; fracture zones, and the early opening of the South Atlantic: J. Geophys. Res., v. 76, p. 6283-6293.

Martini, E., 1971. Standard Tertiary and Quaternary calcareous nannoplanton zonation. In Farinacci, A. (Ed.), Plankt. Conf. Rome, 1970 Proc.: Roma (Tecnoscienza), p. $739-785$.

Matthews, D.J., 1939. Tables of the velocity of sound in pure water and sea water for use in echo-sounding and soundranging. Hydr. Dept. Admiralty, second edition, London.

Maxwell, A.E., Von Herzen, R.P., et al., 1970. Initial Reports of the Deep Sea Drilling Project, Volume 3: Washington (U.S. Government Printing Office).

Müller, G. and Gastner, M., 1974. The "Karbonat-Bombe," a simple device for the determination of the carbonate content in sediments, soils and other materials: Neues Jahrb. Miner., H. 10, p. 466-469.

Perch-Nielsen, K., Supko, P.R., et al., 1975. Leg 39 examines facies changes in South Atlantic: Geotimes, v. 20, p. 2628.

Pitman, W.C. and Talwani, M., 1972. Sea floor spreading in the North Atlantic: Geol. Soc. Am. Bull., v. 83, p. 619646.

Premoli-Silva, I. and Bolli, H., 1973. Late Cretaceous to Eocene planktonic foraminifera and stratigraphy of Leg 15 sites in the Caribbean Sea. In Edgar, N.T., Saunders, J.B., et al., Initial Reports of the Deep Sea Drilling Project, Volume 15: Washington (U.S. Government Printing Office), p. 499-547.

Riedel, W.R. and Sanfilippo, A., in press. Stratigraphy and evolution of tropical Cenozoic radiolarians, Symposium "Marine Plankton and Sediments," Third Plankt. Conf., Kiel, Germany, 1974.

Sclater, J.G., Anderson, R.N., and Bell, M.L., 1971. The elevation of ridges and the evolution of the central eastern Pacific. J. Geophys. Res., v. 76, p. 7888-7915.

Sclater, R.G. and Detrick, R., 1973. Elevation of Mid-ocean Ridges and the basement age of JOIDES Deep Sea Drilling Project site: Geol. Soc. Am. Bull., v. 84, p. 15471554.

Tarling, D.H. and Mitchell, J.G., 1976. Revised Cenozoic polarity scale: Geology, v. 4, p. 133-136.

Thiede, J., in press. The subsidence of aseismic ridges: evidence from sediments on Rio Grande Rise (South Atlantic Ocean).

Thierstein, H.R., 1975. Biostratigraphy of marine Mesozoic sediments by calcareous nannoplankton. 3rd Plankt. Conf. Proc. (in press), (see fig. 12 in Berger and Roth, 1975).

Wentworth, C.K., 1922. A scale of grade and class terms of clastic sediments: J. Geol., v. 30, p. 377.

Wentworth, C.K. and Williams, H., 1932. The classification and terminology of the pyroclastic rocks: Rept. Comm. Sed., Nat. Res. Council, Bull. No. 89, p. 19-53. 


\section{APPENDIX A CLASSIFICATION OF SEDIMENTS}

Several lithologic classifications designed for the construction of the graphic core and hole summaries have been used during the lifetime of the Deep Sea Drilling Project. The classification system described here has been devised by the JOIDES Panel on Sedimentary Petrology and Physical Properties and adopted for use by the JOIDES Planning Committee in March 1974. It was first used on Leg 38; this is the first publication of it in the Initial Reports.

\section{Principles Used in Classification}

1. This is a lithologic summary classification designed to generalize core descriptive material of greater detail into a form suitable for standard core and hole logs. Its systematic use will facilitate core to core and leg to leg comparisons.

2. The classification covers most of the lithologic types encountered so far but does not attempt to be comprehensive. A category "Special Rock Types" allows additional definitions and terminology at the discretion of the shipboard staff for rock types not covered.

3. Sediment names are those in common usage and have been defined within the limits of existing definitions.

4. Categories are based on sediment parameters measured on board ship. Refinement by shore laboratory data is possible but not necessary.

5. The classification is descriptive and genetic implications are not intended.

6. The degree of detail of the classification is scaled to the space limitations of printed graphic hole and core summaries.

\section{Shipboard Parameters Measured}

Sediment and rock names are defined solely on the basis of compositional and textural parameters. The compositional factors are most important for description of those deposits more characteristic of open marine conditions, with textural factors becoming more important for the classification of hemipelagic and near-shore facies. Sediment names are thus based solely upon these parameters as determined in smear slides aided by compositional and textural properties apparent to the naked eye or under the hand lens. Other descriptive parameters include: induration, sediment disturbance, sedimentary structures, and color. The determination of these parameters is as follows:

1) Composition-biogenic and mineral components are estimated in percent from smear slides. $\mathrm{CaCO}_{3}$ content is estimated by using the carbonate bomb available on the ship. Even with rapid use, a value to $\pm 5 \%$ is achievable.

2) Texture-visual estimates from smear slide examination.

3) Induration-The determination of induration is highly subjective, but field geologists have successfully made similar distinctions for many years. The categories suggested here are thought to be practical and significant. The criteria of Moberly and Heath (1971) are used for calcareous deposits; subjective estimate or behavior in core cutting for others. There are three classes for calcareous sediments: two for all others.

a) Calcareous sediments

(i) Soft: Oozes have little strength and are readily deformed under the finger or the broad blade of a spatula.

(ii) Firm: Chalks are partly indurated oozes; they are friable limestones that are readily deformed under the fingernail or the edge of a spatula blade. More indurated chalks are termed limestones (see below).

(iii) Hard: Limestones as a term should be restricted to cemented rocks.

b) The following criteria are recommended for all but calcareous sediments:

(i) If the material is low state of induration as to allow the core to be split with a wire cutter, the sediment name only is used (e.g., silty clay; mud).

(ii) If the core must be cut on the band saw or diamond saw, the suffix 'stone' is used (e.g., silty claystone; mudstone; or shale, if fissile).
4) Sediment Disturbance-Deformational structures are generally of the type found in piston cores, and are usually simple to visualize and interpret.

a) Soft to firm sediment: The following categories are recommended.

(i) Slightly deformed-bedding contacts are slightly bent.

(ii) Moderately deformed-bedding contacts have undergone extreme bowing.

(iii) Very deformed-bedding is completely disturbed, sometimes showing symmetrical diapir-like structure.

(iv) Soupy - water saturated intervals which have lost all aspects of original bedding.

b) Hard sediments: There is also the need to indicate the degree of fracturing in hard sediments/rock. This is best accomplished with a written description in the Lithologic Description portion of the Core Form (Figure Al).

5) Sedimentary structures-In many cores it is extremely difficult to differentiate between natural and coring-induced structures. Consequently, the description of sedimentary structures is optional. The following approach is suggested as a guideline, but the specialist is encouraged to use his own preferred system and set of symbols.

a) Median grain size profile: For the sections of terrigenous sediments, with interbeds of varying textural characteristics, the construction of median grain size profile based on hand lens observations provides a rapid method for illustrating graded and non-graded beds, bed thicknesses, and size distribution.

b) Sedimentary structures: A set of suggested symbols is provided for categories shown on (Figure A2).

6) Color-According to standard Munsell and GSA color charts.

\section{Use of the Core Form}

1) Mandatory Graphic Lithology Column-This graphic column is based on the above classification scheme. Completion of the column using the appropriate symbols (Figure A3) must be done for each site, and will be included in the Initial Core Description (ICD) and Initial Report Volume. The "Special Rock Type" category should be used for sediment types not in the classification.

a) Optional graphic column: If circumstances or the special skills and interests of the shipboard staff indicate an additional modified or different classification, another graphic column may be added to the right of the Mandatory Column using definitions, terminology and symbols that, in the opinion of the shipboard staff, will increase the information yield. This Optional Column must not substitute for the Mandatory Column.

2) Sediment disturbance column-Completion of the sediment disturbance column using symbols and distinctions given below is mandatory.

3) Sedimentary structure columns-Structures may be designated on the core form in the sedimentary structure column parallel to the sediment disturbance column, and/or on the median grain size profile (for the sections of terrigenous sediments, with interbeds of varying textural characteristics). The median grain size profile is located in the lithologic description portion of the core form. A set of suggested symbols for a few more common structures has been prepared by DSDP (Figure A2), but the shipboard geologist is free to use whatever additional symbols he may wish. These optional columns may not substitute for the mandatory sediment disturbance column and must be distinct from it.

4) Lithologic description column-Format, style, and terminology of the descriptive portion of the core sheets are not controlled by the mandatory column scheme, beyond the minimal name assignment which should be derived from this classification. However, colors and additional information on structure and textures should normally be included in the textural section of the core description.

\section{Lithologic Classification Scheme}

The following define compositional class boundaries and use of qualifiers in the lithologic classification scheme:

1) Compositional Class Boundaries

a) $\mathrm{CaCO}_{3}$ content (determined by $\mathrm{CaCO}_{3}$ bomb): $30 \%$ and $60 \%$. With a $5 \%$ precision and given the natural frequency 
SAMPLE CORE FORM

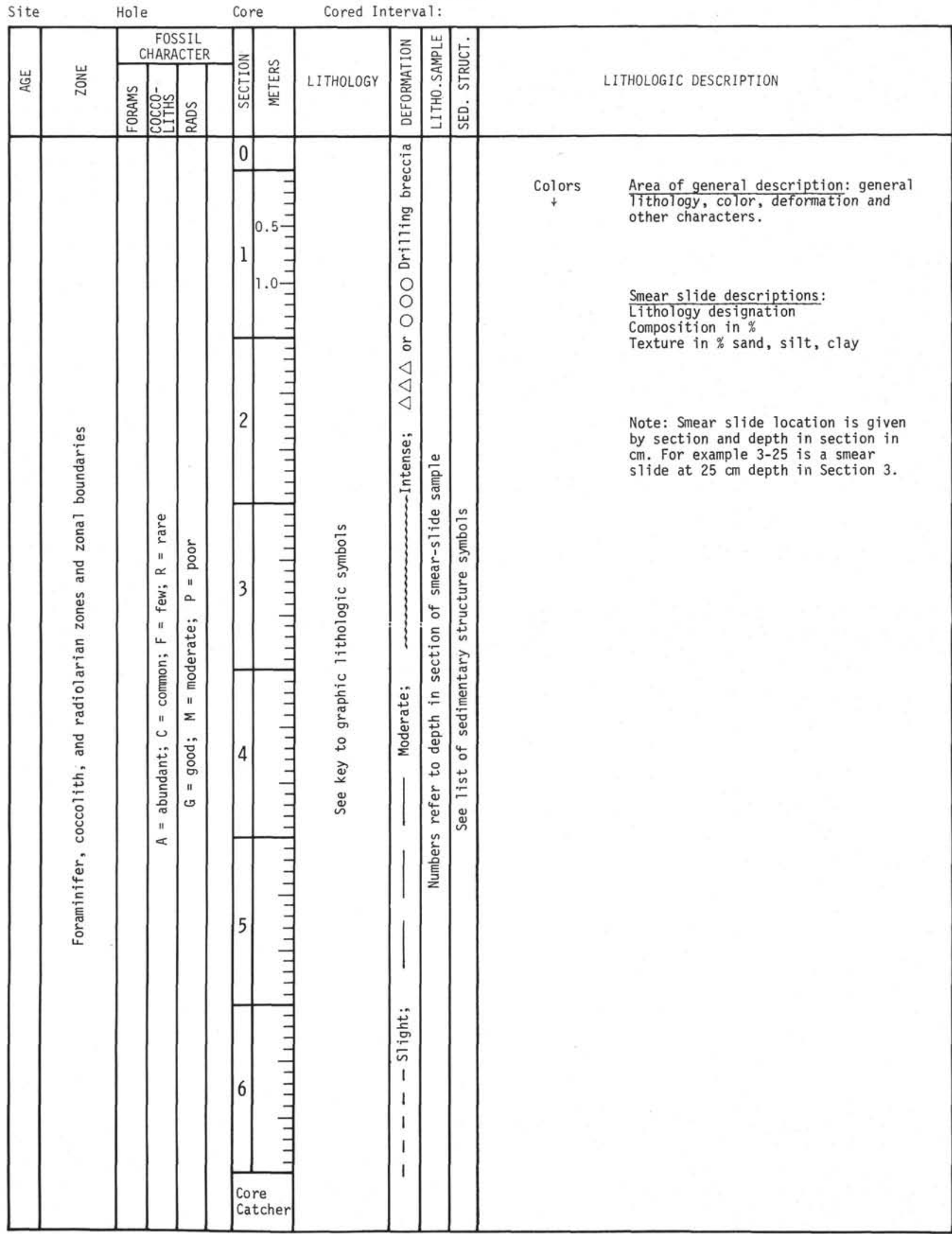

Figure A1. Sample core form. 
Bioturbation

Parallel

laminations

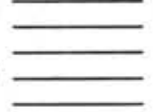

Contorted bedding

(not artificial)

Graded bed

Cross stratification

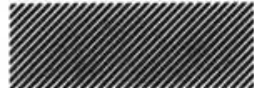

Gradationa 1 contract

(HAND DRAWN)

Figure A2. Sedimentary structure symbols.

distribution of $\mathrm{CaCO}_{3}$ contents in oceanic sediments, these boundaries can be reasonably ascertained.

b) Biogenic opal abundance (expressed as percent siliceous skeletal remains in smear slides): $10 \%, 30 \%$, and $50 \%$. Smear-slide estimates of identifiable siliceous skeletal material generally imply a significantly higher total opal abundance. The boundaries have been set to take this into account.

c) Abundance of authigenic components (zeolites, $\mathrm{Fe}$, and $\mathrm{Mn}$ micronodules etc), fish bones, and other indicators of very slow sedimentation (estimated in smear slides); semiquantitative boundary: common $10 \%$. These components are quite conspicuous and a semiquantitative estimate is adequate. Even a minor influx of calcareous, siliceous, or terrigenous material will, because of the large difference in sedimentation rate, dilute them to insignificance.

d) Abundance of terrigenous detrital material (estimated from smear slides): $30 \%$.

e) Qualifiers: Numerous qualifiers are suggested; the options should be used freely. However, components of less than $5 \%$ (in smear slide) should not be used as a qualifier except in special cases. The most important component should be the last qualifier. No more than two qualifiers should be used.

\section{Description of Sediment Types}

1) Pelagic clay-Principally authigenic pelagic deposits that accumulate at very slow rates. The class is often termed brown clay, or red clay, but since these terms are confusing, they are not recommended.

a) Boundary with terrigenous sediments: Where authigenic components ( $\mathrm{Fe} / \mathrm{Mn}$ micronodules, zeolites), fish debris, etc., become common in smear slides. NOTE: Because of large discrepancy in accumulation rates, transitional deposits are exceptional.
Wavy laminations $\ldots$

Massive or homogeneous

(no symbol necessary)

Load casts (HAND DRAWN)

Sharp contact

(HAND DRAWN)

Sedimentary clasts

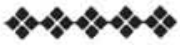

Burrows 000000000

b) Boundary with siliceous biogenic sediments: $<30 \%$ indentifiable siliceous remains.

c) Boundary with calcareous biogenous sediments: Generally the sequence is one passing from pelagic clay through siliceous ooze to calcareous ooze, with one important exception: at the base of many oceanic sections, black, brown or red clays occur directly on basalt, overlain by or grading up into calcareous sediments. Most of the basal clayey sediments are rich in iron, manganese and metallic trace elements. For proper identification they require more elaborate geochemical work than is available on board. These sediments are placed in the "Special Rock" category, but care should be taken to distinguish them from ordinary pelagic clays.

2) Pelagic siliceous biogenic sediments-These are distinguished from the previous category because they have more than $30 \%$ identifiable siliceous microfossils. They are distinguished from the following category by a $\mathrm{CaCO}_{3}$ content of less than $30 \%$. There are two classes: Pelagic biogenic siliceous sediments (containing less than $30 \%$ silt and clay); and transitional biogenic siliceous sediments (containing more than $30 \%$ silt and clay and more than $10 \%$ diatoms).

a) Pelagic biogenic siliceous sediments:

soft: Siliceous ooze (radiolarian ooze, diatom ooze, depending on dominant component).

hard: radiolarite porcellanite diatomite chert

(i) Qualifiers:

Radiolarians dominant: radiolarian ooze or radiolarite.

Diatoms dominant: diatom ooze or diatomite Where uncertain: siliceous (biogenic) ooze, or chert or porcellanite, when containing $>10 \%$ $\mathrm{CaCO}_{3}$, qualifiers are as follows: indeterminate carbonate: calcareous - . nannofossils only: nannofossil -. foraminifers only: foraminifer - . 
Pelagic

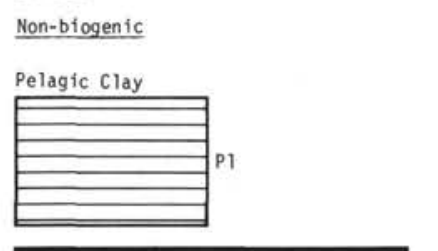

Siliceous Biogenic

Pelagic Siliceous Biogenic - Soft

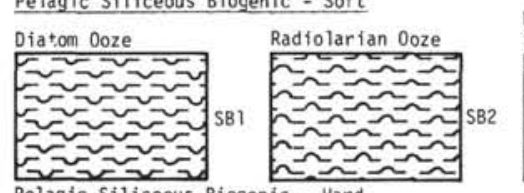

Pelagic Siliceous Biogenic - Hard

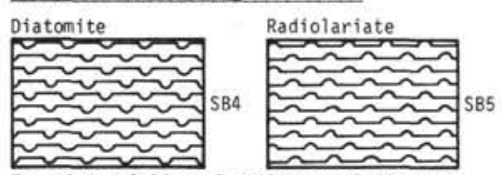

Iransitional Biogenic siliceous Sediments

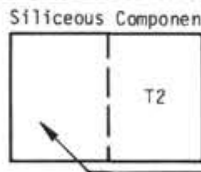

Vertical bar percent

(\%) Designation
for Graphic Log.

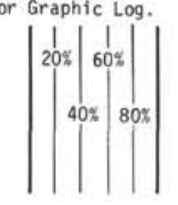

Diatom-Rad or

Siliceous 0oze

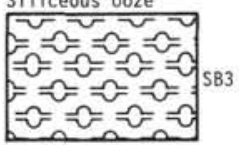

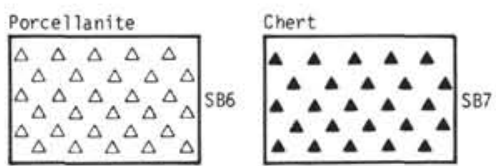

Siliceous Component $>50 \%$

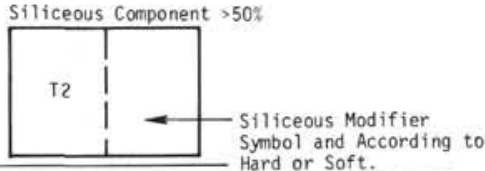

Calcareous Biogenic

Pelagic Biogenic Calcareous - Soft

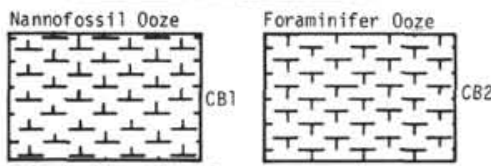

Pelagic Biogenic Calcareous - Firm

Nannofossil Chalk

Pelagic Biogenic Calcareous - Hard

Limestone

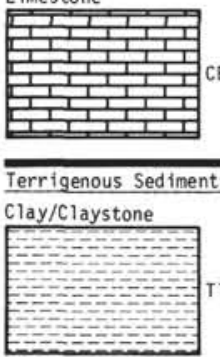

Pyroclastic

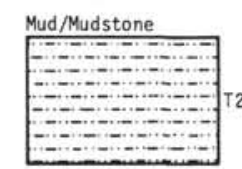

Qualifiers Letter

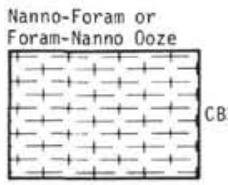

Calcareous 0oze

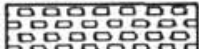

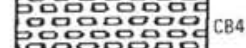
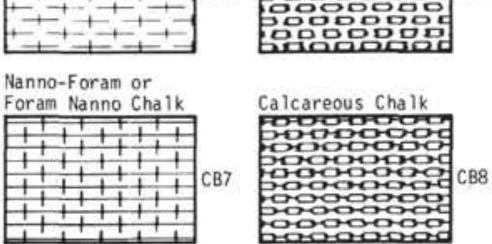

Iransitional Biogenic Calcareous Sediments

Mar1

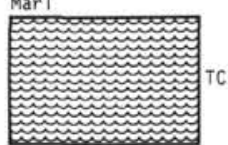

Symbols which may be used for any

new additions to the present.

sediment/rock groups. Assign

number and letter in accordance

with present system.
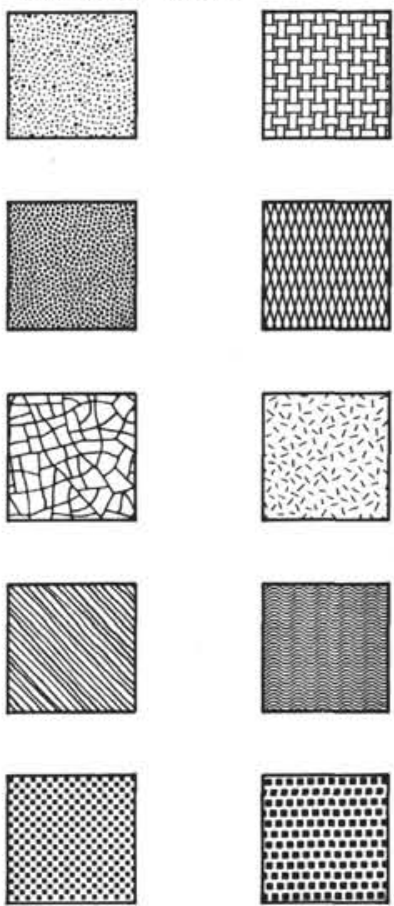
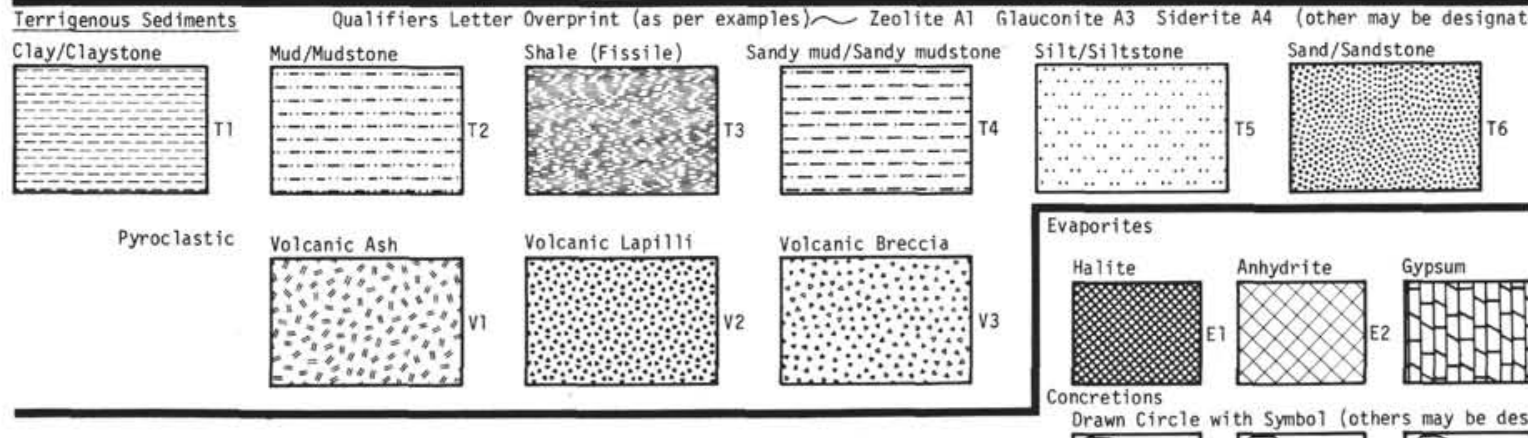

Special Rock Types
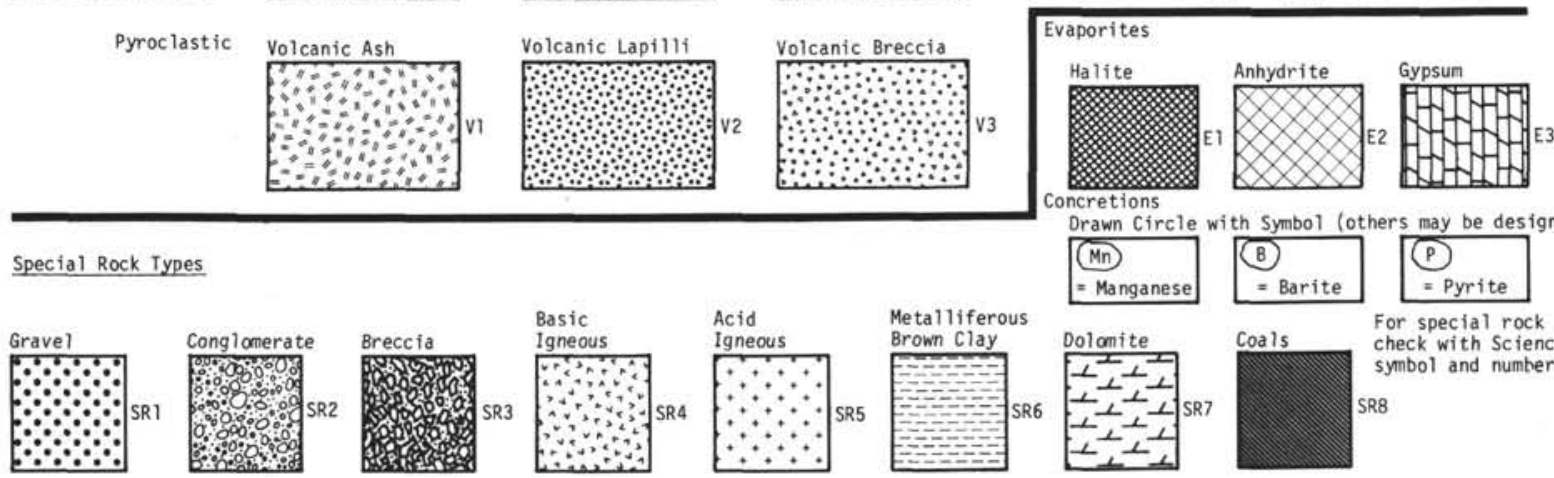

Concretions

Orawn Circle with Symbol (others may be designated)
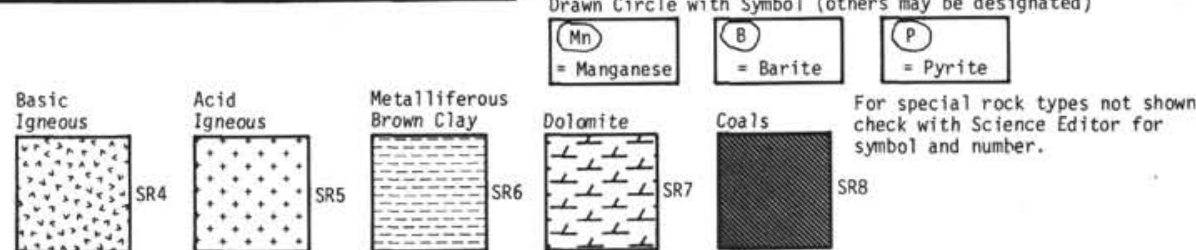

Figure A3. Lithologic symbols. 
nannofossil-foraminifer ..

depending on

dominant

component

foraminiferal-nannofossil -.

b) Transitional biogenic siliceous sediments:

Diatoms $<50 \%$ diatomaceous mud: diatomaceous mudstone: hard

Diatoms $>50 \%$ muddy diatom ooze: muddy diatomite:

soft

hard

Radiolarian equivalents in this category are rare and can be specifically described.

3) Pelagic biogenous calcareous sediments-These are distinguished from the previous categories by a $\mathrm{CaCO}_{3}$ content in excess of $30 \%$. There are two classes: Pelagic biogenic calcareous sediments (containing less than 30\% silt and clay); and transitional biogenic calcareous sediments (containing more than $30 \%$ silt and clay).

a) Pelagic biogenic calcareous sediments:

soft: calcareous ooze

firm: chalk

hard:indurated chalk.

The term limestone should preferably be restricted to cemented rocks.

(i) Compositional Qualifiers [-

Principal components are: nannofossils and foraminifers. One or two qualifiers may be used, for example:

\begin{tabular}{cl}
$\begin{array}{cl}\text { Foram } \% \\
<10\end{array}$ & \multicolumn{1}{c}{ Name } \\
$10-25$ & Foramofossil ooze, chalk, limestone \\
$25-50$ & Nannofossil-foraminifer ooze \\
$>50$ for: & Foraminifer ooze
\end{tabular}

Calcareous sediment containing more than 10\%-20\% identifiable siliceous fossils carry the qualifier radiolarian, diatomaceous, or siliceous depending on the quality of the identification. For example, radiolarian-foraminifer ooze.

b) Transitional biogenic calcareous sediments

(i) $\mathrm{CaCO}_{3}=30 \%-60 \%$ : marly calcareous pelagic sediments.

soft: marly calcareous (or nannofossil, foraminifer, etc.), ooze (see below)

firm: marly chalk

hard: marly limestone

(ii) $\mathrm{CaCO}_{3}>60 \%$ : Calcareous pelagic sediments.

soft: calcareous (or nannofossil, foraminifer, etc.), ooze (see below)

firm: chalk

hard: limestone

NOTE: Sediments containing $10 \%-30 \% \mathrm{CaCO}_{3}$ fall in other classes where they are denoted with the adjective "calcareous." Less than $10 \% \mathrm{CaCO}_{3}$ is ignored

4) Terrigenous sediments

a) Sediment falling in this portion of the classification scheme are subdivided into textural groups on the basis of the relative proportions of three grain size constituents, i.e., clay, silt, and sand. Rocks coarser than sand size are treated as "Special Rock Types." The size limits for these constituents are those defined by Wentworth (1922) (Figure A4).

Five major textural groups are recognized on the accompanying triangular diagram (Figure A5). These groups are defined according to the abundance of clay $(>90 \%, 90-10 \%,<10 \%)$ and the ratio of sand to silt $(>1$ or $<1)$. The terms clay, mud, sandy mud, silt, and sand are used for the soft or unconsolidated sediments which are cut with a wire in the shipboard core splitting process. The hard or unconsolidated equivalents for the same textural groups are claystone, mudstone (or shale, if fissile), sandy mudstone, siltstone, and sandstone. Sedimentary rocks falling into the consolidated category include those which must generally be cut with the band saw or diamond saw. Sands and sandstones may be subdivided further into very fine-, fine-, medium-, coarse-, or very coarse-grained sands and sandstones according to their median grain size.

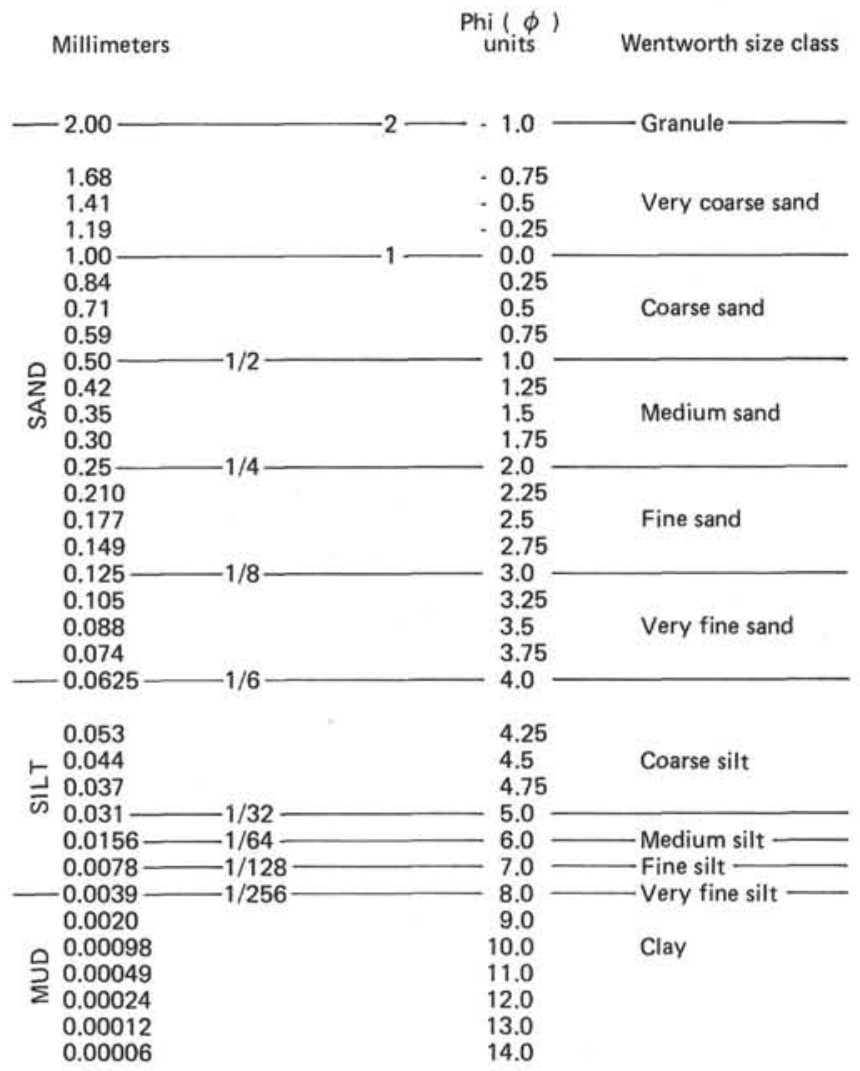

Figure A4. Grade scales for terrigenous sediment.

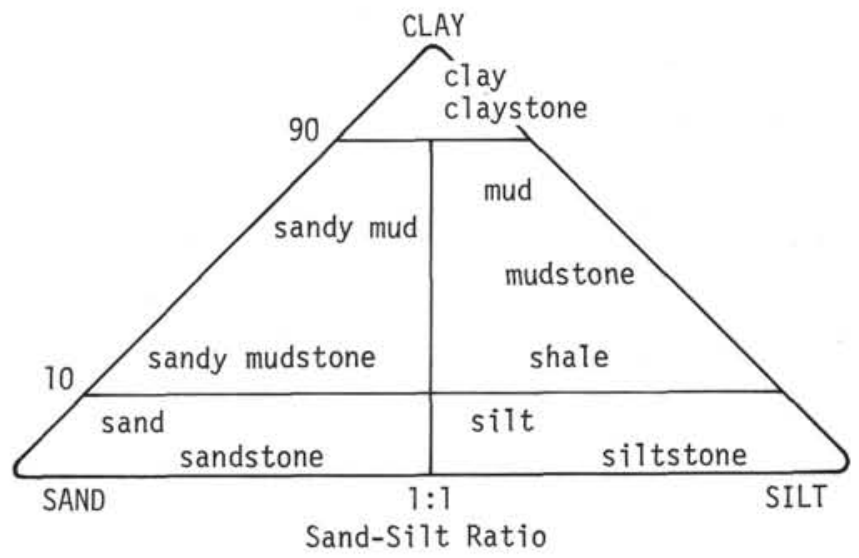

Figure A5. Class boundaries for terrigenous sediments.

(i) Qualifiers-In this group numerous qualifiers are possible, usually based on minor constituents, for example: glauconitic, pyritic, feldspathic. In the sand and sandstone category, conventional divisions such as arkose, graywacke, etc., are, of course, acceptable, providing the scheme is properly identified. Clays, muds, silts, and sands containing $10 \%-30 \% \mathrm{CaCO}_{3}$ shall be called calcareous.

b) Volcanogenic sediments

Pyroclastic rocks are described according to the textural and compositional scheme of Wentworth and Williams (1932). The textural groups are:

Volcanic breccia $>32 \mathrm{~mm}$

Volcanic lapilli $<32 \mathrm{~mm}$

Volcanic ash (tuff, if indurated) $<4 \mathrm{~mm}$

Compositionally, these pyroclastic rocks are described as vitric (glass), crystal or lithic. 
c) Clastic sediments of volcanic provenance are described in the same fashion as the terrigenous sediments, noting the dominant composition of the volcanic grains where possible.

5) Special rock types-The definition and nomenclature of sediment and rock types not included in the system described above are left to the discretion of shipboard scientists with the recommendation that they adhere as closely as practical to conventional terminology.

In this category fall such rocks as:

Intrusive and extrusive igneous rocks;

Evaporites, halite, anhydrite, gypsum (as a rock), etc.;
Shallow water limestone (biostromal, biohermal, coquina, oolite, etc.);

Dolomite;

Gravels, conglomerates, breccias;

Metalliferous brown clays;

Concretions, barite, iron-manganese, phosphorite, pyrite, etc.;

Coal, asphalt, etc.

and many others.

The mandatory graphic lithology column should be completed by shipboard staff with appropriate symbols for intervals containing special rock types. It is imperative that symbols and rock nomenclature be properly defined and described by shipboard staff. 